"Derivative trading and structural breaks in volatility in India: an ICSS approach"

\begin{tabular}{|c|c|c|}
\hline AUTHORS & \multicolumn{2}{|c|}{$\begin{array}{l}\text { Guntur Anjana Raju (D https://orcid.org/0000-0003-4460-6234 } \\
\text { Sanjeeta Shirodkar }\end{array}$} \\
\hline ARTICLE INFO & \multicolumn{2}{|c|}{$\begin{array}{l}\text { Guntur Anjana Raju and Sanjeeta Shirodkar (2020). Derivative trading and } \\
\text { structural breaks in volatility in India: an ICSS approach. Investment Managemen } \\
\text { and Financial Innovations, 17(2), 334-352. doi:10.21511/imfi.17(2).2020.26 }\end{array}$} \\
\hline DOI & \multicolumn{2}{|c|}{ http://dx.doi.org/10.21511/imfi.17(2).2020.26 } \\
\hline RELEASED ON & \multicolumn{2}{|l|}{ Thursday, 02 July 2020} \\
\hline RECEIVED ON & \multicolumn{2}{|l|}{ Tuesday, 28 April 2020} \\
\hline ACCEPTED ON & \multicolumn{2}{|l|}{ Friday, 19 June 2020} \\
\hline & \multicolumn{2}{|l|}{\begin{tabular}{|l|l|}
$(c)$ EY \\
\end{tabular}} \\
\hline LICENSE & \multicolumn{2}{|c|}{$\begin{array}{l}\text { This work is licensed under a Creative Commons Attribution } 4.0 \text { International } \\
\text { License }\end{array}$} \\
\hline JOURNAL & \multicolumn{2}{|c|}{ "Investment Management and Financial Innovations" } \\
\hline ISSN PRINT & \multicolumn{2}{|l|}{$1810-4967$} \\
\hline ISSN ONLINE & \multicolumn{2}{|l|}{$1812-9358$} \\
\hline PUBLISHER & \multicolumn{2}{|c|}{ LLC “Consulting Publishing Company "Business Perspectives" } \\
\hline FOUNDER & \multicolumn{2}{|c|}{ LLC "Consulting Publishing Company "Business Perspectives" } \\
\hline$\sigma^{\circ}$ & 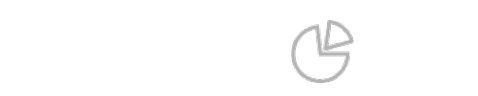 & 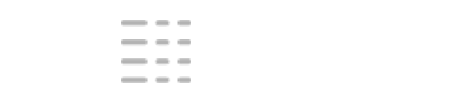 \\
\hline NUMBER OF REFERENCES & NUMBER OF FIGURES & NUMBER OF TABLES \\
\hline 45 & 1 & 4 \\
\hline
\end{tabular}

(c) The author(s) 2023. This publication is an open access article. 


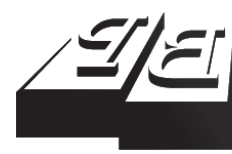

\section{BUSINESS PERSPECTIVES}

()

LLC "CPC "Business Perspectives" Hryhorii Skovoroda lane, 10 Sumy, 40022, Ukraine www.businessperspectives.org

Received on: $28^{\text {th }}$ of April, 2020 Accepted on: $19^{\text {th }}$ of June, 2020 Published on: $2^{\text {nd }}$ of July, 2020

(C) Guntur Anjana Raju, Sanjeeta Shirodkar, 2020

Guntur Anjana Raju, Ph.D., Professor of Commerce, Programme Director for Doctor of Philosophy (Commerce), Goa Business School, Goa University, Goa, India.

Sanjeeta Shirodkar Junior Research Fellow, Goa Business School, Goa University, Goa, India. (Corresponding author)

\title{
DERIVATIVE TRADING AND STRUCTURAL BREAKS IN VOLATILITY IN INDIA: AN ICSS APPROACH
}

\begin{abstract}
Researchers argue that ignoring the structural breaks in the time-series variance can cause significant upward biases in the degree of persistence in estimated GARCH models. Against this backdrop, the present study empirically examines the effect of stock futures on the underlying stock's volatility in India by incorporating the structural breaks with the help of ICSS test and AR $(1)$-GARCH $(1,1)$ model for 30 most liquid and actively traded underlying stocks and their associated futures contracts. The study period ranges from the 1st January 2000 or the listing date of the particular stock (whichever is prior) till 31st March 2019. The study contributes to the on-going debate regarding the effect of derivatives on the underlying stock market's volatility in two ways. Firstly, by taking into consideration the breaks in the volatility and, secondly, studying the effect of single stock futures will allow us to evaluate company-specific response to futures trading directly. The study offers a mixed outcome for the stocks under consideration. However, there is evidence of a decline in unconditional volatility for the majority of the stocks. The overall findings indicate that trading in stock futures may not have any detrimental effect on the underlying stock's volatility.
\end{abstract}

\section{Keywords}

JEL Classification

\section{INTRODUCTION}

Volatility modeling of the financial asset is one of the critical aspects of economic research as it guides the investors on the risk associated with the investment. In India, derivatives trading started in the year 2000 with the launch of futures contracts on the Nifty Index of NSE and Sensex Index of Bombay Stock Exchange (BSE). Options trading began in the Indian markets in June 2001. Ever since then F\&O segment is surging in terms of the number of contracts traded, volume, and offering of new products. The F\&O segment of the NSE surpassed the equity market from 2019 to 2020, with an average daily turnover of ₹ 2,37,590,973 Cr, as compared to ₹ 6,81,983 $\mathrm{Cr}$ in the cash segment (derivatives updates on NSE website, www.nseindia.com, 2019). NSE outperformed the US-based CME group to claim its No.1 ranking in terms of derivatives trading with more than 6 billion contracts traded volume in 2019 (Das \& Sahgal, 2020). Derivatives were introduced to offer a hedging mechanism and enhance the liquidity, thereby increasing the market's overall efficiency. The effect of the listing of derivatives on the underlying market's volatility and, thus, its job in increasing or decreasing the underlying markets' volatility has remained an intense subject of empirical and analytical interest.

Questions about the effect of derivatives trading on underlying market volatility have been empirically addressed in two ways. Firstly, by 
analyzing variation in volatility over the pre- and post-derivatives trading phases and, secondly, by measuring the effect of derivatives trading on the behavior of the underlying markets by comparing the performance with proxies. Moreover, most studies examining the effect of derivatives on the underlying market volatility used some type of GARCH model with dummy variable regressors ${ }^{1}$. However, this approach is based on the underlying presumption that any changes detected during the post-derivatives phase are caused by derivatives trading alone.

An increase in volatility could be the outcome of various other events, such as the initiation of a rolling settlement system, circuit breakers, and changes in regulations, and so on. If the structural breaks in variances of the examined time-series are ignored, the degree of persistence of the GARCH model estimate may be significantly biased. Several studies, such as Diebold (1986), Granger and Hyung (1999), Mikosch and Starica (2000), Diebold and Inoue (2001), have stated that neglecting the structural breaks can lead to spurious GARCH model estimation. The primary reasons for such structural breaks could be the changes in the mechanism of exchange rate systems, global financial markets crisis, or the evolution of the stock markets. The shocks produced by these significant economic or political events may cause a deviation in the financial time-series (Andreou \& Ghysels, 2002; Wang \& Moore, 2009).

\section{LITERATURE REVIEW}

The derivatives market and its effect on the underlying market volatility are debated again and again with supporting and countering theories.

\subsection{Increased volatility due to futures trading}

Wats (2017) examined the effect of the derivatives contracts' expiration on the underlying market's volatility using the GARCH family models. He concluded that spot market volatility has increased during the expiry days and week after the listing of the derivatives. Other studies that find a significant increase in the Index return volatility following the listing of futures include Harris (1989), Brorsen (1991), Lee and Ohk (1992), Antoniou and Holmes (1995), Yao (2016).

\subsection{Decreased volatility due to futures trading}

Others argue that futures' listing potentially reduces the spot market's volatility, thus stabilizing the market. One of the clarifications for the destabilizing theory is that trades in the derivatives market destabilize the underlying market by providing an alternative route for the transmission and reflection of data in the cash market (Cox \& Ross, 1976; Ross, 1989). Gulen and Mayhew (2000) studied the effect of index futures on the volatility of the international equity markets by taking the sample of 21 European nations by applying the BEKK model and GJR-GARCH. They found that the volatility of the underlying market has declined for most of the countries under study.

Similarly, Yilgor, Lidvine, and Mebounou (2016), Chiraz (2016), Bhaumik, Karanasos, and Kartsaklas (2016) used different GARCH family models such as Markow-Switching GARCH, ARFI GARCH, EGARCH, and TGARCH. They found the evidence indicating the decline in the underlying market volatility after listing the derivatives trading. Several studies like Pilar and Rafael (2002), Bandivadekar and Ghosh (2003), Thenmozhi (2002), Raju and Karande (2003), Sarangi and Patnaik (2007) have reported a significant decline in the underlying market volatility in India.

\subsection{Mixed evidence/no impact of futures trading}

Using the GARCH $(1,1)$ model, Rahman (2001) investigated the effect of trading in index futures on the volatility of Dow Jones Industrial Average (DJIA) component stocks and observed no variation in conditional volatility. Mallikajunappa and Afzal (2008), Thenmozhi (2002), Kavussanos, Visvikis, and Alexakis (2008) argued that improvement in the volatility cycle was not due to the listing

1 See Chan (1991), Reyes (1996), Pericli and Koutmos (1997), Mckenzie, Brailsford, and Faff (2001), Tse (1999), Rahman (2001), Gulen and Mayhew (2000), Bandivadekar and Ghosh (2003), Pok and Poshakwale (2006), and Ryoo and Smith (2006). 
of derivatives, but due to many other factors, such as the improved distribution of information and greater transparency.

Due to the increase in the speed of information flow, the stock prices have become more sensitive to the recent innovation in the post-derivative period. Bohl, Salm, and Wilfling (2009), C. Lee, Stevenson, and M. Lee (2014) employed Markow-Switching GARCH, which endogenously identified the distinct volatility regimes, to analyze the effect of derivatives on the volatility and found no influence on the spot market. Mallikajunappa and Afzal (2008), Sarangi and Patnaik (2007) applied the GARCH model with dummy variables and did not find any significant effect of derivatives on the underlying market volatility.

Moreover, the literature is inconclusive about whether the listing of derivatives leads to an increase or decrease in the underlying market's volatility. The vast majority of the studies, which are found in the arena of derivative segments, are concentrated on the effect of index futures on the underlying market. A limited number of studies have been undertaken in the area of single stock futures. Indian studies based on stock futures focus on conceptual clarity or cover only a short period. Research focusing on the index analysis does not consider the stock-specific characteristics, which could also play a significant role in the formation of the volatility.

Table 1. List of selected stocks and their volume
The present study empirically examines the effect of stock futures on India's underlying stock's volatility by incorporating structural breaks. The study contributes to the on-going debate regarding the effect of derivatives on the underlying stock market's volatility in two ways. Firstly, by reinvestigating the issue by applying a distinct analytical technique, which is based on the methodology used by Aggarwal, Inclan, and Leal (1999), Andreou and Ghysels (2002), Malik and Hassan (2004), Kang, Jung, Park, and Yoon (2007). The study attempts to model the underlying stock's volatility with stock futures by considering the breaks in the volatility. It aims at identifying the structural breaks, if any, in the stock prices by applying the ICSS test of Inclan and Tiao (1994). Secondly, studying the effect of single stock futures will allow us to directly evaluate company-specific responses to futures trading, in contrast to the market-wide effect gained from research with index futures.

\section{METHOD}

The Individual Stock Futures (ISF) has proved to be a hugely successful financial instrument on Indian bourses, and NSE has continued to account for the majority of total volumes traded in the ISF segment all over the world. The resulting sample for this study comprises 30 most liquid and actively traded underlying stocks on which futures contracts are available. These 30 stock futures contribute to around

Source: https://www1.nseindia.com

\begin{tabular}{|c|c|c|c|c|c|c|c|}
\hline \multirow{3}{*}{ Stock } & \multicolumn{3}{|c|}{ Volume } & \multirow{3}{*}{ Stock } & \multirow{2}{*}{\multicolumn{3}{|c|}{$\begin{array}{c}\text { Volume } \\
\text { Contracts }\end{array}$}} \\
\hline & \multicolumn{3}{|c|}{ Contracts } & & & & \\
\hline & Futures & Options & Total & & Futures & Options & Total \\
\hline ASHOKLEY & 928 & 1,673 & 2,601 & INFRATEL & 3,358 & 1,383 & 4,741 \\
\hline AUROPHARMA & 1,674 & 2,003 & 3,677 & INFY & 1,759 & 2,441 & 4,200 \\
\hline AXISBANK & 3,645 & 3,697 & 7,342 & ITC & 1,050 & 1,287 & 2,337 \\
\hline BHARTIARTL & 11,550 & 13,551 & 25,101 & JUSTDIAL & 1,371 & 1,179 & 2,550 \\
\hline CIPLA & 1,236 & 1,025 & 2,261 & KOTAKBANK & 1,261 & 803 & 2,064 \\
\hline GLENMARK & 4,891 & 5,215 & 10,106 & LT & 1,309 & 1,322 & 2,631 \\
\hline GRASIM & 2,895 & 1,610 & 4,505 & MARUTI & 1,729 & 3,598 & 5,327 \\
\hline HDFC & 1,469 & 1,418 & 2,887 & RELIANCE & 7,010 & 15,910 & 22,920 \\
\hline HDFCBANK & 2,234 & 1,423 & 3,657 & SBIN & 3,579 & 4,940 & 8,519 \\
\hline HEROMOTOCO & 1,865 & 2,769 & 4,634 & TATAELXSI & 1,447 & 610 & 2,057 \\
\hline IBULHSGFIN & 3,827 & 1,527 & 5,354 & TATASTEEL & 3,581 & 4,489 & 8,070 \\
\hline ICICIBANK & 3,781 & 3,536 & 7,317 & TCS & 1,451 & 2,877 & 4,328 \\
\hline IDEA & 4,913 & 7,224 & 12,137 & VEDL & 1,796 & 1,860 & 3,656 \\
\hline INDIGO & 1,369 & 853 & 2,222 & YESBANK & 10,764 & 6,420 & 17,184 \\
\hline INDUSINDBK & 1,759 & 1,049 & 2,808 & ZEEL & 2,053 & 1,602 & 3,655 \\
\hline
\end{tabular}


$70-80 \%$ of the total trading volume of the $\mathrm{F} \& \mathrm{O}$ segment of NSE, excluding the index futures. The majority of them are also part of the S\&P Nifty Index, the Benchmark Index of NSE. The data extracted for 30 stocks have been procured from the Bloomberg database. The study period will range from the 1st January 2000 or the listing date of the particular stock (whichever is prior) till 31st March 2019.

\subsection{Testing for $A R C H$ effect}

The ARCH test involves testing the existence of heteroscedasticity in the time-series data. Lagrange multiplier (LM) test by Engle helps in checking for $\mathrm{ARCH}$ effect. Let $\varepsilon_{t}=y_{t}-u_{t}$ be the residual series. The squared series $\varepsilon_{t}^{2}$ is utilized to implement the LM test for checking conditional heteroscedasticity. The null hypothesis is stated as follows:

$H_{0}: \quad \alpha_{i}=0, i=1,2, \ldots, q$

versus

$H_{1}: \quad \alpha_{i} \neq 0$, for at least one $i$.

In the linear regression

$\varepsilon_{t}^{2}=\omega+\alpha_{1} \varepsilon_{t-1}^{2}+\ldots+\alpha_{q} \varepsilon_{t-q}^{2}, t=q+1, \ldots, N$,

where $q$ is the length of ARCH lags, and $N$ is the number of observations used in the regression equation.

The test statistic for LM test is defined by:

$$
L M=N R^{2},
$$

where $R^{2}$ is the $R$-squared from the regression of $\varepsilon_{t}^{2}$ in the equation and defined by:

$$
R^{2}=\frac{\text { Regression sum of squares }}{\text { Total sum of squares }} .
$$

\subsection{Testing for multiple structural breaks (Iterated Cumulative Sums of Squares (ICSS) algorithm of Inclan and Tiao (1994))}

Iterative Cumulative Sums of Squares (ICSS) algorithm proposed by Inclan and Tiao (1994) al- lows for detecting multiple breakpoints in the variance in a time series. The idea behind the ICSS algorithm of Inclan and Tiao can be outlined in sequential steps. The unconditional variance of financial time-series is stationary until a sudden break is observed. After that, until the occurrence of the next structural break, the unconditional variance is stationary. This process repeats through time, generating multiple numbers of structural breaks in the unconditional variance in $n$ observations:

$$
\sigma_{t}^{2}= \begin{cases}\tau_{0}^{2} & 1<t<i_{1} \\ \tau_{1}^{2} & i_{1}<t<i_{1} \\ \tau_{M}^{2} & i_{M}<t<i_{1}\end{cases}
$$

To estimate the number of changes and the point in time of variance shifts, a cumulative sum of squared residuals is used, $C_{k}=\sum \varepsilon_{t}^{2}$, $k=1,2 \ldots, n$, where $\left\{\varepsilon_{t}\right\}$ is a series of $t_{\text {ancor- }}$ related random variables with zero mean and unconditional variance $\sigma_{t}^{2}$. Inclan and Tiao define the statistic:

$$
D_{k}=\frac{C_{k}}{C_{n}}-\frac{t k}{n}, k=1,2, \ldots, n, D_{0}=D_{n}=0 .
$$

If no sudden changes occur during the entire sampling duration in the variance of the sequence, $D_{k}$ oscillates about zero. If there are one or more sudden shifts in variance, then the $D_{k}$ statistics will drift either above or below the zero. The ICSS algorithm helps in identifying breaks in variance of the time-series at different points in time.

\subsection{Linking the structural breaks in volatility with trading in stock futures}

First, the dates for the structural breaks in the stocks will be estimated. Later, these structural breaks were matched with the dates of the listing of stock futures on the individual stocks. If a structural break is found within six months of the listing of stock futures, it has been attributed as likely to derivative trading.

AR (1)-GARCH $(1,1)$ is a GARCH family model, in which the mean is determined by a first-order auto-regressive AR (1), with a GARCH $(1,1)$ error: 


$$
\begin{gathered}
x_{t}=u_{t}+\sigma_{t} \varepsilon_{t}, \mathrm{E}\left[\varepsilon_{t}\right]=0, \mathrm{E}\left[\varepsilon_{t}^{2}\right]=1, \varepsilon_{t} \text { i.i.d., } \\
\mu_{t}=\lambda X_{t-1} \\
\sigma_{t}^{2}=a_{0}+a\left(X_{t-1}-\mu_{t-1}\right)^{2}+b \sigma_{t-1}^{2} .
\end{gathered}
$$

Once all the structural breakpoints are identified, dummy variables are created for each detected break. Each dummy variable is denoted with value one onwards from the identified location until the end of the data series and 0 elsewhere.

\section{RESULTS}

Table 2 displays the result of the ADF unit root test. All the variables are non-stationary at the lev- el as the $p$-value is more than $0.05 \%$. Therefore, the Unit Root Test is conducted in the first difference for all the variables. All the series are stationary at the first difference at $1 \%$ level of significance. The results of the $\mathrm{ADF}$ test indicate that all variables are integrated of the same order.

Table 3 depicts the ARCH test results for all 30 stocks traded at the cash segment of NSE. The standard diagnostic test of the Residuals from the model confirms the presence of ARCH effect. There is a presence of the ARCH effect in the closing return series of all the variables.

After detecting the structural breaks in the return series of selected highly traded 30 stocks, an at-

\begin{tabular}{|c|c|c|c|c|c|c|c|c|c|}
\hline \multirow[b]{2}{*}{ Stock } & \multicolumn{2}{|c|}{ Spot } & \multicolumn{2}{|c|}{ Futures } & \multirow[b]{2}{*}{ Stock } & \multicolumn{2}{|c|}{ Spot } & \multicolumn{2}{|c|}{ Futures } \\
\hline & $\begin{array}{c}\text { ADF at } \\
\text { level }\end{array}$ & $\begin{array}{l}\text { ADF at first } \\
\text { difference }\end{array}$ & $\begin{array}{c}\text { ADF at } \\
\text { level }\end{array}$ & $\begin{array}{l}\text { ADF at first } \\
\text { difference }\end{array}$ & & $\begin{array}{c}\text { ADF at } \\
\text { level }\end{array}$ & $\begin{array}{l}\text { ADF at first } \\
\text { difference }\end{array}$ & $\begin{array}{c}\text { ADF at } \\
\text { level }\end{array}$ & $\begin{array}{l}\text { ADF at first } \\
\text { difference }\end{array}$ \\
\hline \multirow{2}{*}{ ASHOKLEY } & -2.669 & -77.9823 & -1.8401 & -25.085 & \multirow{2}{*}{ INFRATEL } & -1.903 & -252.625 & -1.840 & -251.084 \\
\hline & $(-0.079)$ & $(-0.00)$ & $(-0.361)$ & $(-0.00)$ & & $(-0.330)$ & $(-0.000)$ & $(-0.361)$ & $(-0.000)$ \\
\hline \multirow{2}{*}{ AUROPHARMA } & -3.075 & -14.3857 & -3.067 & -14.026 & \multirow{2}{*}{ INFY } & -2.8434 & -264.133 & -2.696 & -264.045 \\
\hline & $(-0.112)$ & $(-0.000)$ & $(-0.114)$ & $(-0.000)$ & & $(-0.052)$ & $(-0.000)$ & $(-0.074)$ & $(-0.000)$ \\
\hline \multirow{2}{*}{ AXISBANK } & -2.407 & -216.989 & -2.473 & -218.720 & \multirow{2}{*}{ ITC } & -1.793 & -435.009 & -1.887 & -297.513 \\
\hline & $(-0.139)$ & $(-0.000)$ & $(-0.121)$ & $(-0.000)$ & & $(-0.389)$ & $(-0.000)$ & $(-0.333)$ & $(-0.000)$ \\
\hline \multirow{2}{*}{ BHARTIARTL } & -2.496 & $(-240.736)$ & -420.76 & -420.769 & \multirow{2}{*}{ JUSTDIAL } & -1.436 & -169.532 & -1.450 & -218.429 \\
\hline & $(0.116)$ & $(-0.000)$ & $(-0.000)$ & $(0.000)$ & & $(-0.565)$ & $(-0.000)$ & $(-0.558)$ & $(-0.000)$ \\
\hline \multirow{2}{*}{ CIPLA } & -1.471 & -305.751 & -1.505 & -189.269 & \multirow{2}{*}{ KOTAKBANK } & -2.743 & -254.133 & -2.596 & -254.045 \\
\hline & $(-0.548)$ & $(-0.000)$ & $(-0.531)$ & $(-0.000)$ & & $(-0.072)$ & $(-0.000)$ & $(-0.064)$ & $(-0.000)$ \\
\hline \multirow{2}{*}{ GLENMARK } & -1.476 & -296.195 & -1.189 & -186.673 & \multirow{2}{*}{ LT } & \multirow{2}{*}{$\begin{array}{l}-2.496 \\
(0.116)\end{array}$} & -240.736 & -420.769 & -420.769 \\
\hline & $(-0.546)$ & $(-0.000)$ & $(-0.681)$ & $(-0.000)$ & & & $(-0.000)$ & $(-0.000)$ & $(0.000)$ \\
\hline \multirow{2}{*}{ GRASIM } & -1.903 & -252.625 & -1.840 & -251.084 & \multirow{2}{*}{ MARUTI } & -1.683 & -435.009 & -1.797 & -298.513 \\
\hline & $(-0.330)$ & $(-0.000)$ & $(-0.361)$ & $(-0.000)$ & & $(-0.389)$ & $(-0.000)$ & $(-0.333)$ & $(-0.000)$ \\
\hline \multirow{2}{*}{ HDFC } & -2.843 & -264.133 & -2.696 & -264.045 & \multirow{2}{*}{ RELIANCE } & -1.803 & -242.625 & -1.740 & -241.084 \\
\hline & $(-0.052)$ & $(-0.000)$ & $(-0.074)$ & $(-0.000)$ & & $(-0.320)$ & $(-0.000)$ & $(-0.351)$ & $(-0.000)$ \\
\hline \multirow{2}{*}{ HDFCBANK } & -2.283 & -174.557 & -2.256 & -169.916 & \multirow{2}{*}{ SBIN } & \multirow{2}{*}{$\begin{array}{l}-2.496 \\
(0.116)\end{array}$} & -240.736 & -420.769 & -420.769 \\
\hline & $(-0.177)$ & $(-0.000)$ & $(-0.186)$ & $(-0.000)$ & & & $(-0.000)$ & $(-0.000)$ & $(0.000)$ \\
\hline \multirow{2}{*}{ HEROMOTOCO } & -1.219 & -116.178 & -1.098 & -128.5 & \multirow{2}{*}{ TATAELXSI } & -1.471 & -305.751 & -1.505 & -189.269 \\
\hline & $(-0.668)$ & $(-0.000)$ & $(-0.718)$ & -0.0001 & & $(-0.548)$ & $(-0.000)$ & $(-0.531)$ & $(-0.000)$ \\
\hline & -0.992 & -161.898 & -0.692 & -162.498 & & -1.476 & -296.195 & -1.189 & -186.673 \\
\hline TBULHSGFIN & $(-0.758)$ & $(-0.000)$ & $(-0.846)$ & $(-0.000)$ & TATASTEEL & $(-0.546)$ & $(-0.000)$ & $(-0.681)$ & $(-0.000)$ \\
\hline & -1.783 & -425.009 & -1.897 & -298.513 & & -1.903 & -252.625 & -1.840 & -251.084 \\
\hline ICICIBANK & $(-0.389)$ & $(-0.000)$ & $(-0.333)$ & $(-0.000)$ & ICS & $(-0.330)$ & $(-0.000)$ & $(-0.361)$ & $(-0.000)$ \\
\hline & -2.843 & -264.133 & -2.696 & -264.045 & & -2.283 & -174.557 & -2.256 & -169.916 \\
\hline IDEA & $(-0.052)$ & $(-0.000)$ & $(-0.074)$ & $(-0.000)$ & VEDL & $(-0.177)$ & $(-0.000)$ & $(-0.186)$ & $(-0.000)$ \\
\hline & 0.895 & -195.973 & 0.538 & -277.977 & & -1.211 & -116.178 & -1.098 & -128.5 \\
\hline INDIGO & $(-0.995)$ & $(-0.000)$ & $(-0.988)$ & $(-0.000)$ & & $(-0.668)$ & $(-0.000)$ & $(-0.718)$ & $(-0.000)$ \\
\hline & -1.360 & -216.679 & -1.370 & -216.604 & & -0.992 & -161.898 & -0.692 & -162.498 \\
\hline INDUSINDBK & $(-0.603)$ & $(-0.000)$ & $(-0.598)$ & $(-0.000)$ & $\angle E E L$ & $(-0.758)$ & $(-0.000)$ & $(-0.846)$ & $(-0.000)$ \\
\hline
\end{tabular}
tempt has been made to associate these structural

Table 2. Unit root test (augmented Dickey-Fuller test)

Note: ( ) denote $p$-value. 
Table 3. Results of ARCH test

\begin{tabular}{|c|c|c|c|c|c|}
\hline Variables & $p$-value & Inference & Variables & $p$-value & Inference \\
\hline ASHOKLEY & 0.000 & Present & INFRATEL & 0.000 & Present \\
\hline AUROPHARMA & 0.000 & Present & INFY & 0.000 & Present \\
\hline AXISBANK & 0.000 & Present & ITC & 0.000 & Present \\
\hline BHARTIARTL & 0.000 & Present & JUSTDIAL & 0.000 & Present \\
\hline CIPLA & 0.000 & Present & KOTAKBANK & 0.000 & Present \\
\hline GLENMARK & 0.000 & Present & LT & 0.000 & Present \\
\hline GRASIM & 0.000 & Present & MARUTI & 0.000 & Present \\
\hline HDFC & 0.000 & Present & RELIANCE & 0.000 & Present \\
\hline HDFCBANK & 0.000 & Present & SBIN & 0.000 & Present \\
\hline HEROMOTOCO & 0.000 & Present & TATAELXSI & 0.000 & Present \\
\hline IBULHSGFIN & 0.000 & Present & TATASTEEL & 0.000 & Present \\
\hline ICICIBANK & 0.000 & Present & TCS & 0.000 & Present \\
\hline IDEA & 0.000 & Present & VEDL & 0.000 & Present \\
\hline INDIGO & 0.000 & Present & YESBANK & 0.000 & Present \\
\hline INDUSINDBK & 0.000 & Present & ZEEL & 0.000 & Present \\
\hline
\end{tabular}

breaks with the listing dates of stock futures on individual stocks. The stocks, which have displayed similar patterns in terms of changes in persistence in volatility, unconditional volatility, and rate of adjustment to new information (measured by a), have been grouped. The detailed analysis after incorporating detected structural breaks into the AR (1)-GARCH $(1,1)$ Model is presented in Appendix. Stocks were divided into seven categories, viz. Panel A, Panel B, Panel C, Panel D, Panel E, Panel F, and Panel G. This classification is based on the influence of stock futures on the underlying volatility.
If a structural break is observed six months after listing the stock futures, it is associated with trading in futures. After this structural break date, the change in persistence of volatility, unconditional volatility, and rate of adjustment to new information (denoted by $\boldsymbol{\alpha}$ ) is observed and reported in Table 4. In the case of AUROPHARMA, ICICIBANK, and JUSTDIAL, the total persistence increases, while $\boldsymbol{\alpha}$ and unconditional volatility declined for the period after this break (Panel A). On the contrary, ASHOKLEY, AXISBANK, HDFCBANK, INDUSINDBK, INFRATEL, RELIANCE, and TCS have shown a downfall in

Table 4. Impact of stock futures on the volatility of underlying stocks

\begin{tabular}{|c|c|c|c|c|}
\hline \multirow{3}{*}{ Stock } & \multicolumn{4}{|c|}{ Impact on the volatility } \\
\hline & \multirow{2}{*}{$\begin{array}{l}\text { If structural break associated with } \\
\text { stock futures trading }\end{array}$} & \multicolumn{3}{|c|}{ Direction of impact } \\
\hline & & Persistence & $\alpha$ & $\begin{array}{l}\text { Unconditional } \\
\text { Volatility }\end{array}$ \\
\hline \multicolumn{5}{|c|}{ Panel A } \\
\hline AUROPHARMA & Yes & $\downarrow$ & $\uparrow$ & $\uparrow$ \\
\hline ICICIBANK & Yes & $\downarrow$ & $\uparrow$ & $\uparrow$ \\
\hline JUSTDIAL & Yes & $\downarrow$ & $\uparrow$ & $\uparrow$ \\
\hline \multicolumn{5}{|c|}{ Panel B } \\
\hline ASHOKLEY & Yes & $\downarrow$ & $\downarrow$ & $\downarrow$ \\
\hline AXISBANK & Yes & $\downarrow$ & $\downarrow$ & $\downarrow$ \\
\hline HDFCBANK & Yes & $\downarrow$ & $\downarrow$ & $\downarrow$ \\
\hline INDUSINDBK & Yes & $\downarrow$ & $\downarrow$ & $\downarrow$ \\
\hline INFRATEL & Yes & $\downarrow$ & $\downarrow$ & $\downarrow$ \\
\hline RELIANCE & Yes & $\downarrow$ & $\downarrow$ & $\downarrow$ \\
\hline TCS & Yes & $\downarrow$ & $\downarrow$ & $\downarrow$ \\
\hline \multicolumn{5}{|c|}{ Panel C } \\
\hline BHARTIARTL & Yes & $\uparrow$ & $\uparrow$ & $\downarrow$ \\
\hline INFY & Yes & $\uparrow$ & $\uparrow$ & $\downarrow$ \\
\hline MARUTI & Yes & $\uparrow$ & $\uparrow$ & $\downarrow$ \\
\hline
\end{tabular}


Table 4 (cont.). Impact of stock futures on the volatility of underlying stocks

\begin{tabular}{|c|c|c|c|c|}
\hline \multirow{3}{*}{ Stock } & \multicolumn{4}{|c|}{ Impact on the volatility } \\
\hline & \multirow{2}{*}{$\begin{array}{l}\text { If structural break associated with } \\
\text { stock futures trading }\end{array}$} & \multicolumn{3}{|c|}{ Direction of impact } \\
\hline & & Persistence & $\alpha$ & $\begin{array}{c}\text { Unconditional } \\
\text { Volatility }\end{array}$ \\
\hline \multicolumn{5}{|c|}{ Panel D } \\
\hline CIPLA & Yes & $\downarrow$ & $\uparrow$ & $\downarrow$ \\
\hline HDFC & Yes & $\downarrow$ & $\uparrow$ & $\downarrow$ \\
\hline INDIGO & Yes & $\downarrow$ & $\uparrow$ & $\downarrow$ \\
\hline $\mathrm{LT}$ & Yes & $\downarrow$ & $\uparrow$ & $\downarrow$ \\
\hline \multicolumn{5}{|c|}{ Panel E } \\
\hline GRASIM & Yes & $\uparrow$ & $\downarrow$ & $\downarrow$ \\
\hline HEROMOTOCO & Yes & $\uparrow$ & $\downarrow$ & $\downarrow$ \\
\hline ITC & Yes & $\uparrow$ & $\downarrow$ & $\downarrow$ \\
\hline SBIN & Yes & $\uparrow$ & $\downarrow$ & $\downarrow$ \\
\hline TATASTEEL & Yes & $\uparrow$ & $\downarrow$ & $\downarrow$ \\
\hline ZEEL & Yes & $\uparrow$ & $\downarrow$ & $\downarrow$ \\
\hline \multicolumn{5}{|c|}{ Panel F } \\
\hline IDEA & Yes & $\uparrow$ & $\uparrow$ & $\uparrow$ \\
\hline \multicolumn{5}{|c|}{ Panel G } \\
\hline GLENMARK & No & - & - & - \\
\hline IBULHSGFIN & No & - & - & - \\
\hline KOTAKBANK & No & - & - & - \\
\hline TATAELXSI & No & - & - & - \\
\hline VEDL & No & - & - & - \\
\hline YESBANK & No & - & - & - \\
\hline \multirow{2}{*}{ Total $=30$} & $Y e s=24$ & Increased $=10$ & Increased $=11$ & Increased $=4$ \\
\hline & $\mathrm{No}=6$ & Decreased $=14$ & Decreased = 13 & Decreased $=20$ \\
\hline
\end{tabular}

the total persistence, unconditional volatility, and $\boldsymbol{\alpha}$ (Panel B).

Panel C comprises of BHARTIARTL, INFY, and MARUTI. There is a decline in the unconditional volatility, but its persistence, as well as $\boldsymbol{\alpha}$, has increased after the occurrence of the structural break. Panel D consists of CIPLA, HDFC, INDIGO, and LT for which the total persistence and unconditional volatility have declined, but $\boldsymbol{\alpha}$ has increased during the observed structural break in volatility. There is observed an increase in $\boldsymbol{\alpha}$, and reduction in the total persistence and the unconditional volatility of GRASIM, HEROMOTOCO, ITC, SBIN, TATASTEEL, and ZEEL for the period after the listing of stock futures (Panel E). However, no structural break is observed within six months after the listing of stock futures for GLENMARK, IBULHSGFIN, KOTAKBANK, TATAELXSI, and VEDL, and YESBANK (Panel G).

No structural break was observed within six months after listing the stock futures for six out of thirteen stocks. Unconditional volatility has declined for twenty out of twenty-four stocks for which structural breaks were observed within six months after the listing of stock futures. It is noted that the unconditional volatility has declined for the majority of the stocks after the listing of futures contracts. Total persistence has risen for ten stocks while declined for fourteen stocks. On the other hand, $\boldsymbol{\alpha}$ has increased for eleven stocks, while it has decreased for thirteen stocks.

\section{DISCUSSION}

Through this study, an attempt has been made to model the underlying stock's volatility with stock futures by taking into consideration the breaks in the volatility. Several studies, such as Diebold (1986), Granger and Hyung (1999), Mikosch and Starica (2000), Diebold and Inoue (2001), have stated that neglecting the structural breaks can lead to spurious GARCH model estimation. Therefore, Iterated Cumulative Sums of Squares (ICSS) algo- 
rithm of Inclan and Tiao (1994) was applied for detecting the multiple structural breaks for 30 highly traded and liquid stocks.

If a break is observed within six months after the listing of stock futures, then unconditional volatility, the nature of changes in total persistence, and $\boldsymbol{\alpha}$ have been examined. Reduction in the unconditional volatility was observed for twenty out of thirty stocks after incorporating detected structural breaks into the AR(1)-GARCH $(1,1)$ model. It is noted that the unconditional volatility has declined for the majority of the stocks after the listing of futures contracts. Total persistence has risen for ten stocks while declined for fourteen stocks. On the other hand, $\boldsymbol{\alpha}$ has increased for eleven stocks, while it has decreased for thirteen stocks.

\section{CONCLUSION}

Through this analysis, any consistent patterns were not found in terms of changes in total persistence, unconditional volatility, and a for the underlying stocks for the period after the relevant breaks. The mixed outcome could be due to stock-specific characteristics, which could also play a significant role in the formation of the volatility. Consequently, the listing of stock futures may not have any clear effect on the underlying stock's volatility. The findings of the study reveal that the unconditional volatility has declined for the majority of the stocks after the listing of futures contracts. The analysis findings suggest that trading in stock futures may not have any detrimental effect on the underlying stock's volatility. These findings are in line with conclusions drawn by Badhani, Harish, and Chauhan (2008), Malik and Shah (2016).

\section{AUTHOR CONTRIBUTIONS}

Conceptualization: Sanjeeta Shirodkar.

Data curation: Sanjeeta Shirodkar.

Formal analysis: Sanjeeta Shirodkar.

Investigation: Guntur Anjana Raju, Sanjeeta Shirodkar.

Methodology: Guntur Anjana Raju, Sanjeeta Shirodkar

Project administration: Sanjeeta Shirodkar.

Resources: Guntur Anjana Raju.

Software: Guntur Anjana Raju, Sanjeeta Shirodkar.

Supervision: Guntur Anjana Raju.

Validation: Guntur Anjana Raju.

Visualization: Sanjeeta Shirodkar.

Writing - original draft: Sanjeeta Shirodkar.

Writing - review \& editing: Guntur Anjana Raju.

\section{REFERENCES}

1. Aggarwal, R., Inclan, C., \& Leal, R. (1999). Volatility in Emerging Stock Markets. Journal of Financial and Quantitative Analysis, 34(1), 33-55. Retrieved from https:// ideas.repec.org/a/cup/jfinqa/ v34y1999i01p33-55_00.html

2. Andreou, E., \& Ghysels, E. (2002) Detecting Multiple Breaks in Financial Market. Journal of
Applied Econometrics, 17, 579-600. https://doi.org/10.1002/jae.684

3. Antoniou, A., \& Holmes, P. (1995). Futures trading, information and spot price volatility: evidence for the FTSE-100 stock index futures contract using GARCH. Journal of Banking and Finance, 19(1), 117129. https://doi.org/10.1016/03784266(94)00059-C
4. Awan, A., \& Shah, S. M. A. (2014). The Price and Volume Effect of Single-Stock Futures Trading on the Pakistani stock market. The Lahore Journal of Business, 2, 1-32. Retrieved from https://pdfs.semanticscholar.org/c795/151143e32056f bed6f88d26059f93c170b24.pdf

5. Badhani, K. N., Harish, B., \& Chauhan, A. K. (2008). Derivative Trading and Structural Changes in 
Volatility Derivative Trading and Structural Changes in Volatility. Paper presented at IDIGR Conference (pp. 1-29). Retrieved from http://www.igidr.ac.in/ conf/money/mfc_10/Harish\%20 Bisht_A\%20Chauhan_K\%20 N\%20Badhani.pdf

6. Bae, S. C., Kwon, T. H., \& Park, J. W. (2004). Futures trading, spot market volatility, and market efficiency: The case of the Korean index futures markets. The Journal of Futures Markets, 24(12), 11951228. https://www.sciencedirect. com/science/article/abs/pii/03784 2669400059C?via\%3Dihub

7. Bandivadekar, S., \& Ghosh, S. (2003). Derivatives and Volatility on Indian Stock Markets. In Reserve Bank of India Occasional Papers (Vol. 24). Retrieved from https://www.rbi.org.in/upload/ Publications/PDFs/60616.pdf

8. Bhaumik, S., Karanasos, M., \& Kartsaklas, A. (2016). The informative role of trading volume in an expanding spot and futures market. Journal of Multinational Financial Management, 35, 24-40. https://doi.org/10.1016/j.mulfin.2016.03.002

9. Bohl, M. T., Salm, C. A., \& Wilfling, B. (2009). Do Individual Index Futures Investors Destabilize the Underlying Spot Market? The Journal of Futures Markets, 31(1), 81-101. https://doi. org/10.1002/fut.20460

10. Brorsen, B. W. (1991). Futures trading, transaction costs, and stock market volatility. Journal of Futures Markets, 11(2), 153163. https://doi.org/10.1002/ fut.3990110203

11. Chan, K. (1991). A Further Analysis of the Lead-Lagg Relationship Between the Cash Market and Stock Index Futures Market. The Review of Financial Studies, 4(4), 657-684. Retrieved from https://ideas.repec.org/a/ oup/rfinst/v5y1992ilp123-52.html

12. Chiraz, A. (2016). Does the Index Futures Destabilize the Underlying Spot Market? Some Evidence from Frensh Stock Exchange. Business and Economics Journal, 7(3). Retrieved from https://www. hilarispublisher.com/open-access/ does-the-index-futures-destabilize-the-underlying-spot-marketsomeevidence-from-frensh-stockexchange-2151-6219-1000244.pdf

13. Cox, J. C., \& Ross, S. A. (1976). A Survey of Some New Results in Financial Option Pricing Theory. The Journal of Finance, 31(2), 383-402. https://doi. org/10.1111/j.1540-6261.1976. tb01893.x

14. Das, S., \& Sahgal, R. (2020). NSE turns world's largest exchange in derivatives trading. The Economic Times. Retrieved April 1, 2020, from Economic Times website: https://economictimes.indiatimes. com/markets/stocks/news/nseturns-worlds-largest-exchangein-derivatives-trading/articleshow/73359798.cms

15. Diebold, F.X. (1986) Modeling the Persistence of Conditional Variances: A Comment. Econometric Reviews, 5(1), 51-56. https://doi. org/10.1080/07474938608800096

16. Diebold, F. X., \& Inoue, A. (2001). Long memory and regime switching. Journal of Econometrics, 105(1), 131-159. https://doi.org/10.1016/S03044076(01)00073-2

17. Granger, C. W. J., \& Hyung, N. (1999). Occasional Structural Breaks and Long Memory. Marine Ecology Progress Series, 11(3), 399-421. https://doi.org/10.1016/j. jempfin.2003.03.001

18. Gulen, H., \& Mayhew, S. (2000). Stock Index Futures Trading and Volatility in International Equity Markets. The Journal of Futures Markets, 20(7), 661-685. Retrieved from https://www.krannert.purdue.edu/faculty/hgulen/futures. pdf

19. Harris, L. (1989). S \& P 500 Cash Stock Price Volatilities. The Journal of Finance, 44(5), 11551175. Retrieved from https://www. jstor.org/stable/2328637?seq=1

20. Jithendranathan, T. (2010). Effect of Single Stock Futures on the Volatility of Underlying Russian Stocks. Global Business \& Finance Review, 15(2). Retrieved from https://papers.ssrn.com/sol3/papers.cfm?abstract_id=2488069

21. Kang, S. H., Jung, J., Park, K., \& Yoon, S. (2007). Sudden Changes in Variance and Volatility Persistence in Asian Foreign Exchange Markets. The Journal of the Korean Economy, 11(1), 129-143. Retrieved from http:// www.akes.or.kr/eng/papers(2009)/ sang_hoon_kang.pdf

22. Kavussanos, M. G., Visvikis, I. D., \& Alexakis, P. D. (2008). The Lead-Lag Relationship Between Cash and Stock Index Futures in a New Market. European Financial Management, 14(5), 1007-1025. https://doi.org/10.1111/j.1468036X.2007.00412.x

23. Khan, S. U., \& Rizwan, F. (2008). Trading Volume and Stock Returns: Evidence from Pakistan's Stock Market. International Review of Business Research Papers, 4(2), 151-162. Retrieved from https:// pdfs.semanticscholar.org/ac5a/ eeefb21d2efa4011ec73d2664b7240841c9f.pdf

24. Lee, C. L., Stevenson, S., \& Lee, M. L. (2014). Futures trading, Spot Price Volatility and Market Efficiency: Evidence from European Real Estate Securities Futures. Journal of Real Estate Finance and Economics, 48, 299-322. Retrieved from https:// ideas.repec.org/a/kap/jrefec/ v48y2014i2p299-322.html

25. Lee, S. B., \& Ohk, K. Y. (1992). Stock index futures listing and structural change in time-varying volatility. Journal of Futures Markets, 12(5), 493-509. https:// doi.org/10.1002/fut.3990120502

26. Malik, F., \& Hassan, S. A. (2004). Modeling volatility in sector index returns with GARCH models using an iterated algorithm. Journal of Economics and Finance, 28(2), 211-225. https://doi. org/10.1007/BF02761612

27. Malik, I. R., \& Shah, A. (2016). The Impact of Single Stock Futures on Market Efficiency and Volatility: A Dynamic CAPM Approach. Emerging Markets Finance and Trade, 53(2), 339-356. https://doi.org/10.1080/154049 6X.2016.1210507 
28. Mallikarjunappa, T., and Afzal (2008). The Impact of Derivatives on Stock Market Volatility: A Study of the Nifty Index. Asian Academy of Management Journal of Accounting and Finance, 4(2), 43-65.

29. Mckenzie, M. D., Brailsford, T. J., \& Faff, R. W. (2001). New Insights into the Impact of the Introduction of Futures Trading on Stock Price Volatility. The Journal of Futures Markets, 21(3), 237-255. https://doi.org/10.1002/10969934(200103)21:3\%3C237::AIDFUT3\%3E3.0.CO;2-0

30. Mikosch, T., \& Starica, C. (2000). Limit Theory for the Sample Autocorrelations and Extremes of a GARCH $(1,1)$ Process. The Annals of Statistics, 28(5), 14271451. Retrieved from https://www. jstor.org/stable/2674101? seq =1

31. Pericli, A., \& Koutmos, G. (1997). Index futures and options and stock market volatility. Journal of Futures Markets, 17(8), 957-974. https:// doi.org/10.1002/(SICI)10969934(199712)17:8\%3C957::AIDFUT6\%3E3.0.CO;2-K

32. Pilar, C., \& Rafael, S. (2002). Does derivatives trading destabilize the underlying assets? Evidence from the Spanish stock market. Applied Economics Letters, 9(2), 107-110. https://www.tandfonline.com/doi/ abs/10.1080/13504850110049441

33. Pok, W. C., \& Poshakwale, S. (2006). The impact of the introduction of futures contracts on the spot market volatility : the case of Kuala Lumpur Stock Exchange. Applied Financial Economics, 14(2), 37-41. https:// doi.org/10.1080/0960310042000 176416

34. Rahman, S. (2001). The introduction of derivatives on the dow jones industrial average and their impact on the volatility of component stocks. Journal of Futures Markets, 21(7), 633-653. https://doi.org/10.1002/fut.1702

35. Raju, M. T., \& Karande, K. (2003). Price Discovery and Volatility on NSE Futures Market. Retrieved from https://www. sebi.gov.in/sebi_data/attachdocs/1293096997650.pdf

36. Reyes, M. G. (1996). Index Futures Trading and Stock Price Volatility: Evidence from Denmark and France. Journal of Economics and Finance, 20(3), 81-88. Retrieved from https://link.springer.com/ article/10.1007/BF02920609

37. Ross, G. J. (1989). Modeling Financial Volatility in the Presence of Abrupt Changes. The Journal of Finance, $X L I V(1), 1-17$. Retrieved from https://arxiv.org/ abs/1212.6016

38. Ryoo, H., \& Smith, G. (2006) The impact of stock index futures on the Korean stock market The impact of stock index futures on the Korean stock market. Applied Financial Economics, 14(4), 37-41. https://doi.org/10.1080/096031004 2000201183

39. Sarangi, S. P., \& Patnaik, K. U. S. (2011). Impact of Futures and Options on the Underlying Market Volatility: An Empirical Study on S\&P CNX Nifty Index. SSRN Electronic Journal. https://doi. org/10.2139/ssrn.962036

40. Thenmozhi, M. (2002). Do the Ser P CNX Nifty Index And Nifty Futures Really Lead/Lag? Error Correction Model: A Co-integration Approach. Retrieved from https:// www1.nseindia.com/research/ content/research_initiative.htm

41. Tse, Y. (1999). Price Discovery and Volatility Spillovers in the DJIA Index and Futures Markets. Journal of future markets, 19(8), 911-930. https:// doi.org/10.1002/(SICI)10969934(199912)19:8\%3C911::AIDFUT4\%3E3.0.CO;2-Q

42. Wang, P., \& Moore, T. (2009). Sudden changes in volatility: The case of five central European stock markets. Journal of International Financial Markets, Institutions and Money, 19(1), 33-46. Retrieved from https://ideas.repec.org/a/eee/ intfin/v19y2009i1p33-46.html

43. Wats, S. (2017). Expiration Day Impact on the Indian Spot Market Volatility. NMIMS Management Review, XXXIII, 88-97. Retrieved from https://management-review. nmims.edu/wp-content/uploads/2017/01/expiration-day-impact-on-the-indian-spot-marketvolatility-sangeeta-wats.pdf

44. Yilgor, A. G., Lidvine, C., \& Mebounou, C. (2016). The Effect of Futures Contracts on the Stock Market Volatility : An Application on Istanbul Stock Exchange. Journal of Business, Economics and Finance, 5(3), 307-317. Retrieved from https://www.researchgate. net/publication/338396003_The effect_of_futures_contracts_on_ the_stock_market_volatility

45. Yao, Y. (2016). The Impact of Stock Index Futures on Spot Market Volatility. International Conference on Education, Sports, Arts and Management Engineering (ICESAME 2016), 1244-1247. Retrieved from https://www. atlantis-press.com/proceedings/ icesame-16/25851103 


\section{APPENDIX}

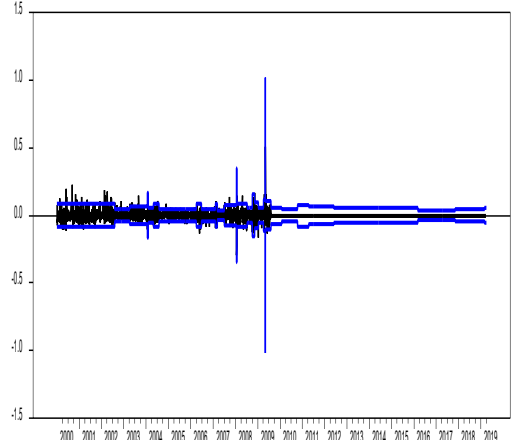

ASHOKLEY

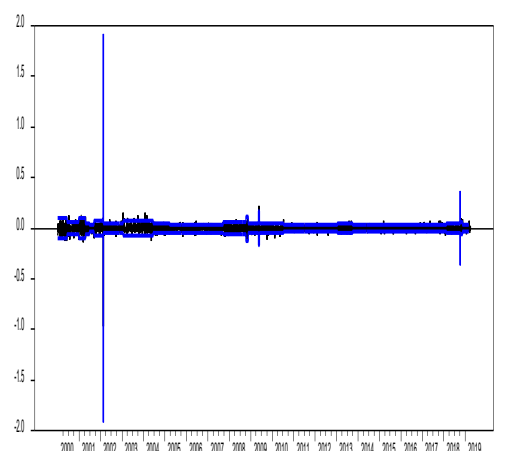

BHARTIARTL

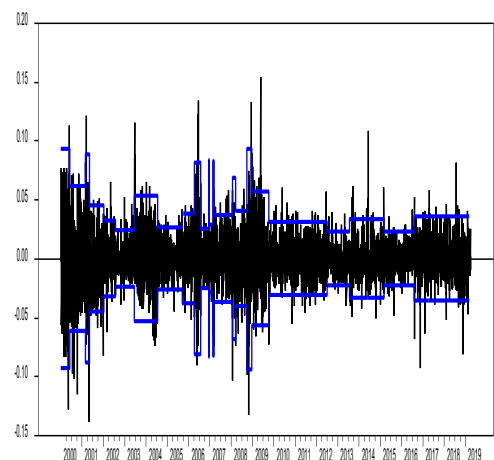

GRASIM

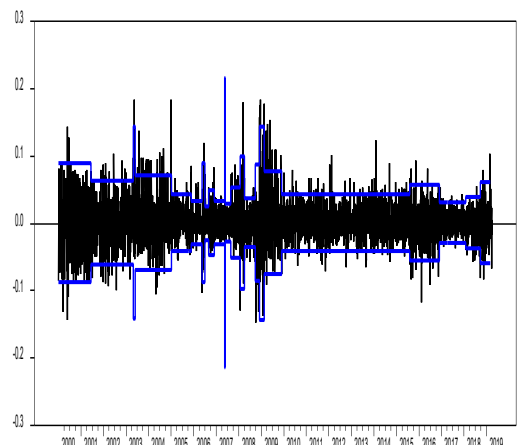

HEROMOTOCO

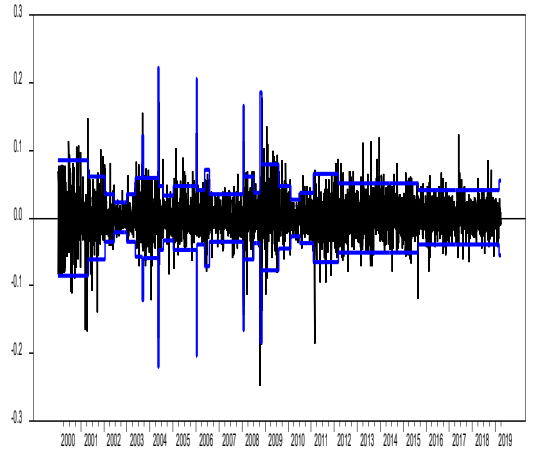

AUROPHARMA

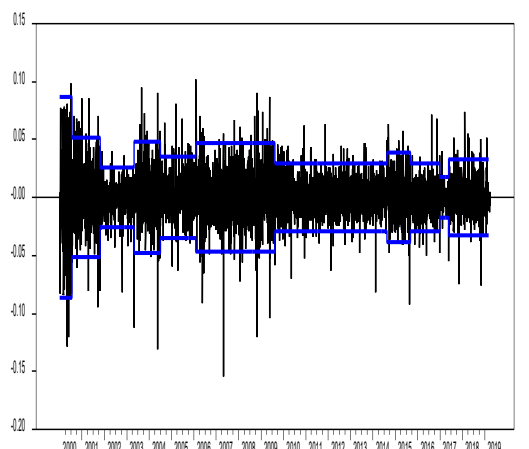

CIPLA

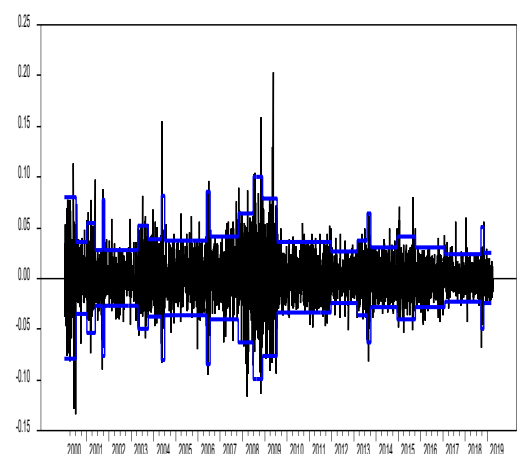

HDFCBANK

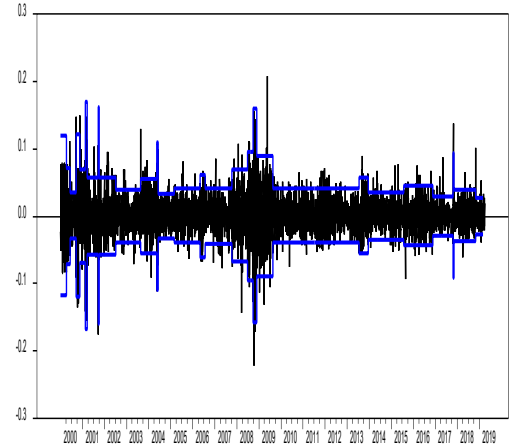

ICICIBANK

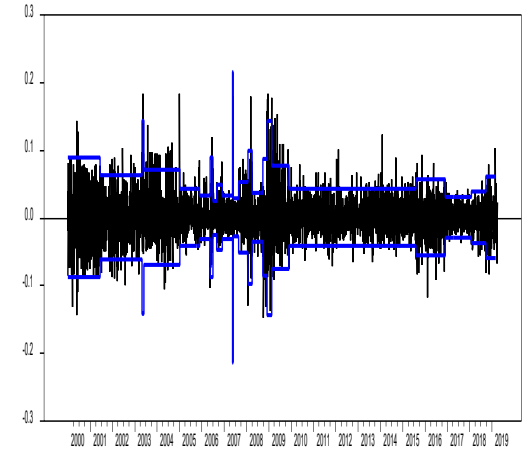

AXISBANK

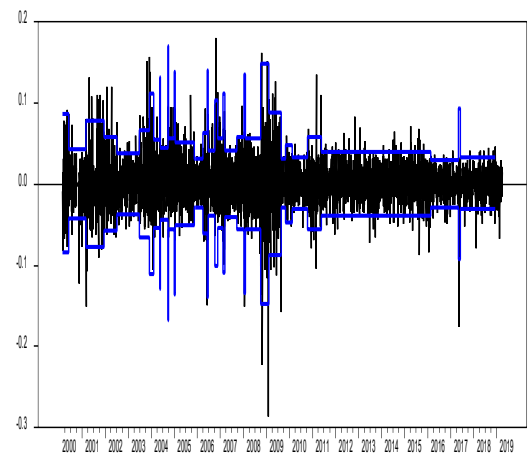

GLENMARK

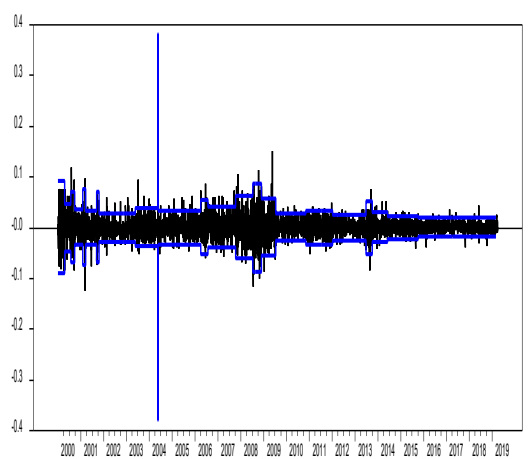

HDFC

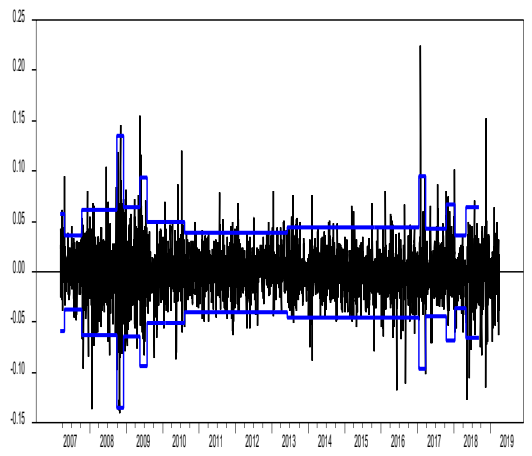

IDEA 

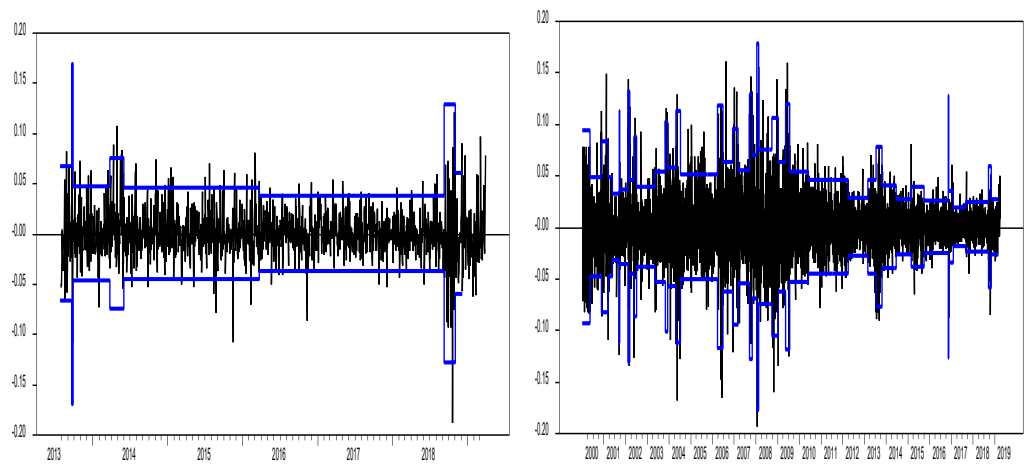

IBULHSGFIN

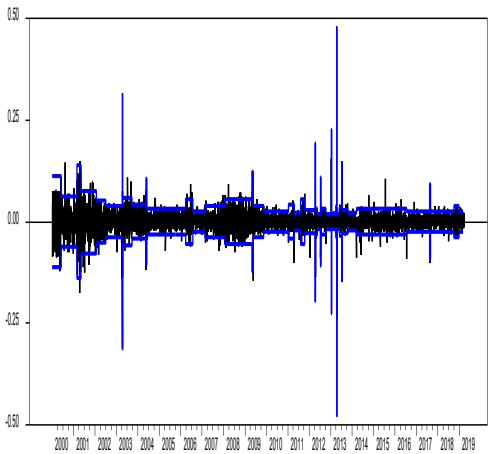

INFY

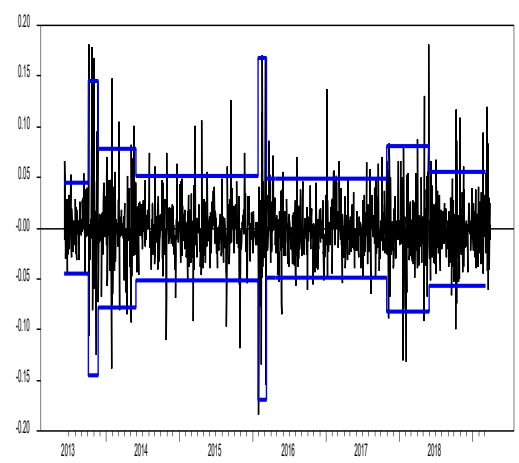

JUSTDIAL

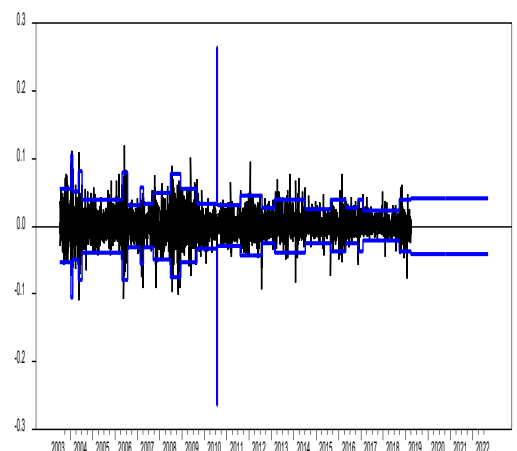

MARUTI
INDUSINDBK

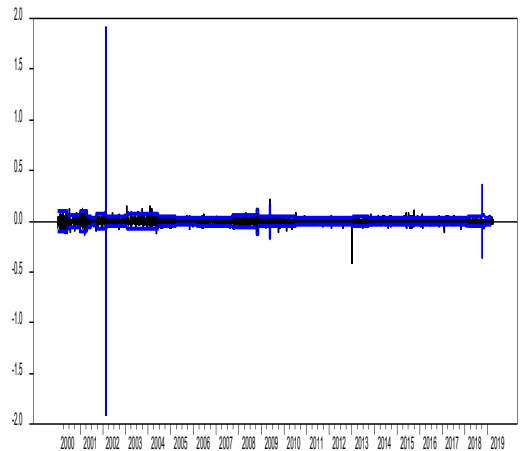

INFRATEL

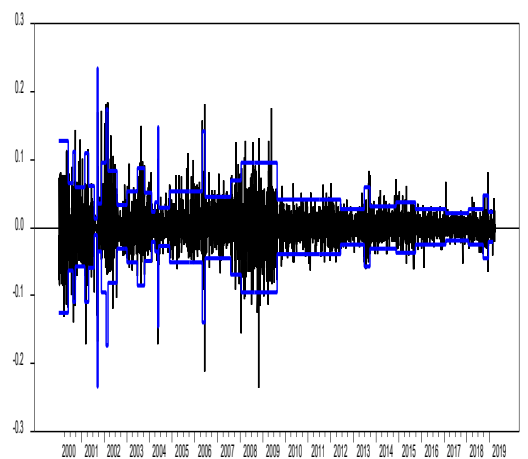

KOTAKBANK

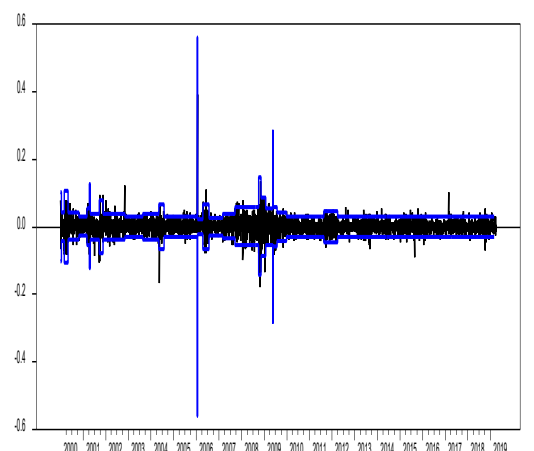

RELIANCE

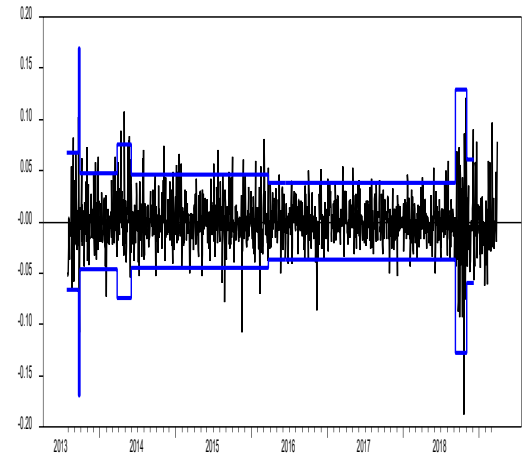

INDIGO

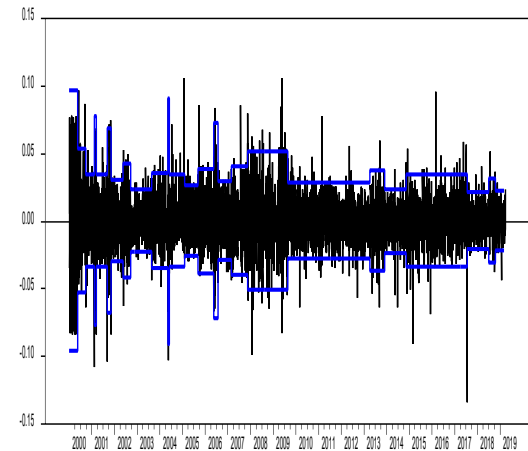

ITC

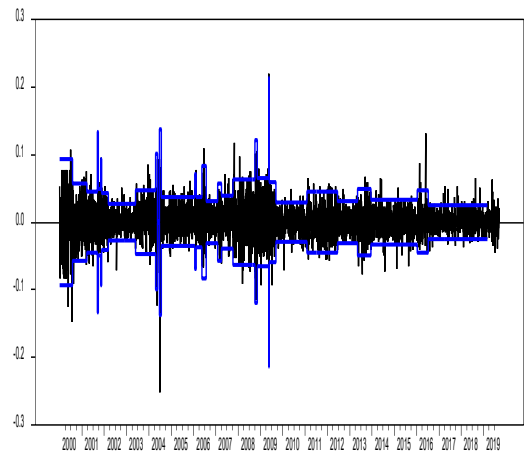

LT

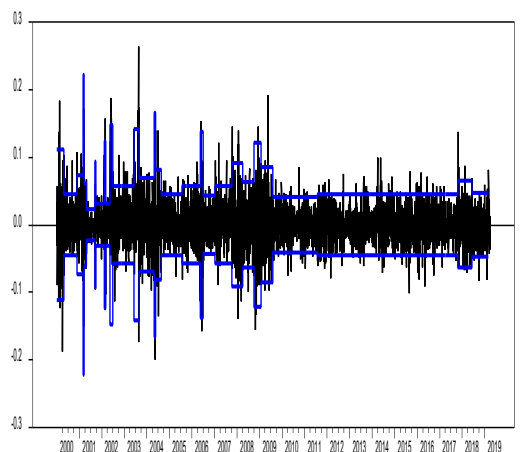

SBIN 


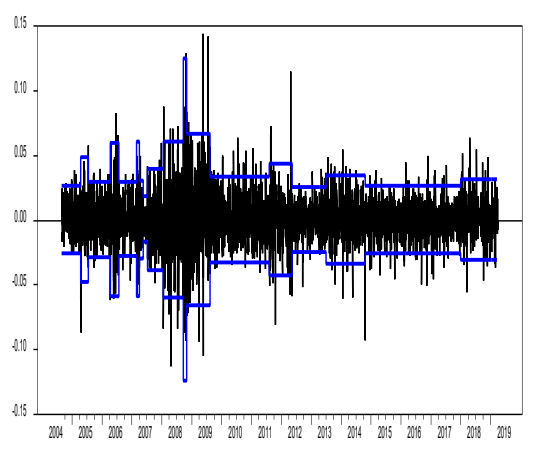

TCS

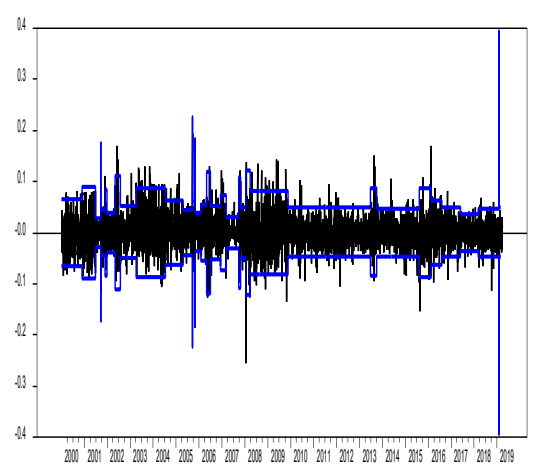

VEDL

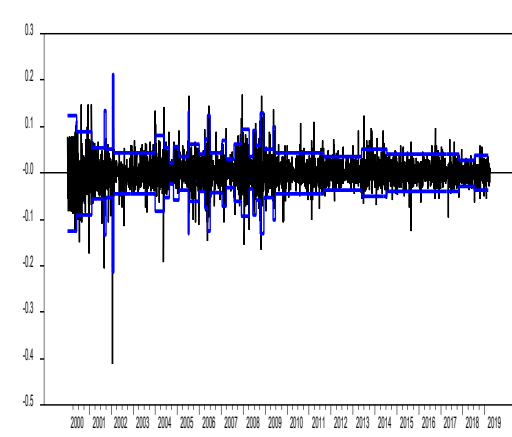

TATAELXSI

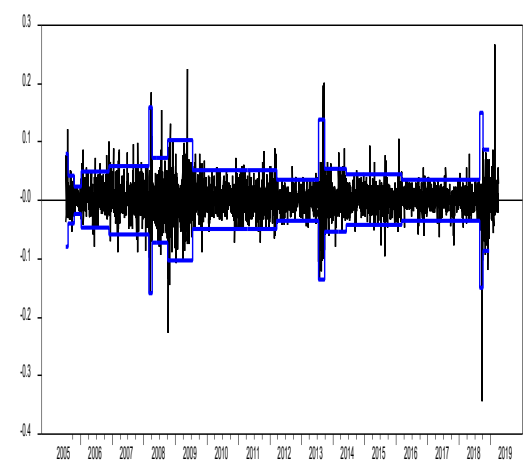

YESBANK

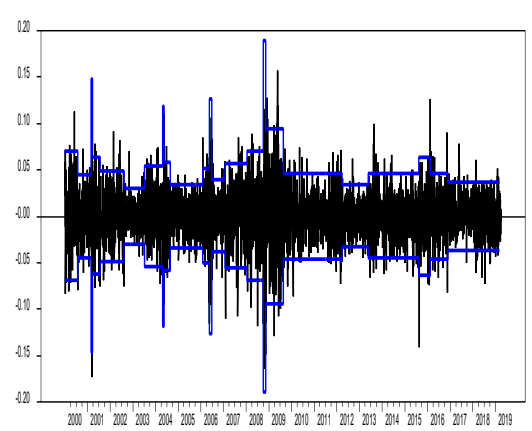

TATASTEEL

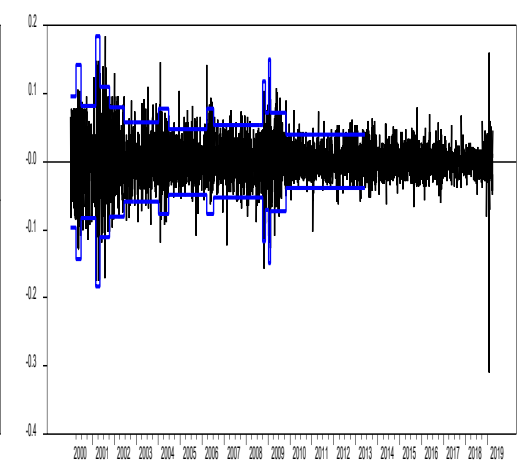

ZEEL

Figure 1. Multiple Structural Breaks (Iterated Cumulative Sums of Squares (ICSS) algorithm of Inclan and Tiao (1994)

\begin{tabular}{|c|c|c|c|c|c|}
\hline Period & $\omega$ & $\alpha$ & B & $\begin{array}{l}\text { Total Persistence: } \\
\qquad(\alpha+\beta)\end{array}$ & $\begin{array}{l}\text { Unconditional Volatility: } \\
\qquad \omega /(1-\alpha-\beta)\end{array}$ \\
\hline \multicolumn{6}{|c|}{ Volatility Breaks in ASHOKLEY } \\
\hline \multicolumn{6}{|c|}{ Date of commencement of Derivative trading: 20-04-2005 } \\
\hline 05/07/2002_30/12/2004 & 1.311 & 0.194 & 0.669 & 0.864 & 9.611 \\
\hline 31/12/2004_17/11/2005 & 0.717 & 0.165 & 0.764 & 0.928 & 9.994 \\
\hline 18/11/2005_29/09/2008 & 1.830 & 0.157 & 0.630 & 0.786 & 8.553 \\
\hline 30/09/2008_02/11/2009 & -0.021 & 0.109 & 0.898 & 1.007 & 3.062 \\
\hline $03 / 11 / 2009 \_10 / 02 / 2010$ & 0.513 & 0.038 & 0.868 & 0.906 & 5.461 \\
\hline 11/02/2010_20/05/2011 & 0.732 & 0.155 & 0.718 & 0.872 & 5.719 \\
\hline 21/05/2011_16/02/2016 & 0.684 & 0.060 & 0.762 & 0.823 & 3.856 \\
\hline $17 / 02 / 2016 \_02 / 06 / 2017$ & 0.954 & 0.366 & 0.397 & 0.763 & 4.021 \\
\hline 03/06/2017_29/03/2019 & 1.270 & 0.067 & 0.449 & 0.516 & 2.623 \\
\hline \multicolumn{6}{|c|}{ Volatility Breaks in AUROPHARMA } \\
\hline \multicolumn{6}{|c|}{ Date of commencement of Derivative trading: 12-05-2005 } \\
\hline 05/01/2000_30/04/2001 & 12.687 & 0.411 & -0.084 & 0.327 & 18.856 \\
\hline 10/05/2001_17/09/2003 & 0.064 & 0.087 & 0.910 & 0.997 & 22.097 \\
\hline $18 / 09 / 2003 \quad 11 / 05 / 2004$ & 4.754 & 0.043 & 0.425 & 0.468 & 8.938 \\
\hline $12 / 05 / 2004 \quad 05 / 08 / 2005$ & 0.071 & -0.076 & 1.063 & 0.987 & 5.376 \\
\hline 06/08/2005_09/01/2006 & 3.321 & 0.076 & 0.353 & 0.429 & 5.818 \\
\hline 10/01/2006_15/01/2008 & 0.492 & 0.113 & 0.761 & 0.874 & 3.899 \\
\hline 16/01/2008_04/08/2009 & 0.962 & 0.057 & 0.882 & 0.940 & 15.928 \\
\hline 05/08/2009_09/02/2010 & 2.761 & -0.091 & 0.581 & 0.490 & 5.409 \\
\hline 10/02/2010_09/02/2011 & 1.707 & 0.043 & 0.341 & 0.384 & 2.770 \\
\hline
\end{tabular}




\begin{tabular}{|c|c|c|c|c|c|}
\hline Period & $\omega$ & $\alpha$ & B & $\begin{array}{l}\text { Total Persistence: } \\
(\alpha+b)\end{array}$ & $\begin{array}{l}\text { Unconditional Volatility: } \\
\qquad \omega /(1-\alpha-6)\end{array}$ \\
\hline 10/02/2011_07/03/2012 & 1.148 & 0.152 & 0.741 & 0.893 & 10.707 \\
\hline 08/03/2012_28/08/2015 & 1.129 & 0.042 & 0.790 & 0.831 & 6.690 \\
\hline 29/08/2015_29/03/2019 & 0.550 & 0.076 & 0.784 & 0.861 & 3.951 \\
\hline
\end{tabular}

Volatility Breaks in AXISBANK

\begin{tabular}{|c|c|c|c|c|c|}
\hline \multicolumn{6}{|c|}{ Date of commencement of Derivative trading: 20-04-2005 } \\
\hline 05/01/2000_16/11/2001 & 3.256 & 0.310 & 0.540 & 0.850 & 21.713 \\
\hline 17/11/2001_01/01/2003 & 0.142 & 0.266 & 0.784 & 1.051 & -2.803 \\
\hline 02/01/2003_06/06/2005 & 0.172 & 0.096 & 0.888 & 0.984 & 10.853 \\
\hline 07/06/2005_18/01/2006 & 3.323 & 0.085 & 0.411 & 0.497 & 6.601 \\
\hline 19/01/2005_18/01/2008 & 2.728 & 0.259 & 0.453 & 0.712 & 9.478 \\
\hline 19/01/2008_18/08/2009 & 2.281 & 0.079 & 0.815 & 0.894 & 21.560 \\
\hline 19/08/2009_07/06/2012 & 1.175 & 0.146 & 0.558 & 0.704 & 3.962 \\
\hline 08/06/2012_20/11/2014 & 0.056 & 0.039 & 0.940 & 0.979 & 2.657 \\
\hline 21/11/2014_24/09/2015 & 0.840 & 0.032 & 0.703 & 0.735 & 3.169 \\
\hline 25/09/2015_31/01/2017 & 1.287 & -0.019 & 0.264 & 0.245 & 1.705 \\
\hline 01/02/2017_29/03/2019 & 1.037 & 0.276 & 0.123 & 0.400 & 1.726 \\
\hline
\end{tabular}

Volatility Breaks in BHARTIARTL

\begin{tabular}{|c|c|c|c|c|c|}
\hline \multicolumn{6}{|c|}{ Date of commencement of Derivative trading : 20-04-2005 } \\
\hline 05/01/2000_22/11/2001 & 3.995 & 0.197 & 0.462 & 0.658 & 11.698 \\
\hline 23/11/2001_20/01/2003 & 1.738 & 0.367 & 0.372 & 0.739 & 6.649 \\
\hline 21/01/2003_14/06/2004 & 1.967 & 0.023 & 0.808 & 0.831 & 11.613 \\
\hline 15/06/2004_22/07/2005 & 2.967 & 0.059 & 0.465 & 0.524 & 6.234 \\
\hline 23/07/2005_19/09/2007 & 0.620 & 0.134 & 0.710 & 0.843 & 3.959 \\
\hline 20/09/2007_10/10/2008 & 2.520 & 0.004 & 0.678 & 0.682 & 7.925 \\
\hline 11/10/2008_27/05/2009 & 1.247 & 0.444 & 0.575 & 1.019 & -64.730 \\
\hline 28/05/2009_12/07/2010 & 3.565 & 0.257 & 0.166 & 0.423 & 6.175 \\
\hline 13/07/2010_10/01/2013 & 2.566 & 0.110 & 0.274 & 0.384 & 4.166 \\
\hline 11/01/2013_29/03/2019 & 2.790 & 0.058 & 0.089 & 0.147 & 3.272 \\
\hline \multicolumn{6}{|c|}{ Volatility Breaks in CIPLA } \\
\hline \multicolumn{6}{|c|}{ Date of commencement of Derivative trading: 02-07-2001 } \\
\hline 05/01/2000_19/07/2000 & 13.355 & 0.229 & 0.021 & 0.249 & 17.791 \\
\hline 20/07/2000_23/10/2001 & 1.187 & 0.049 & 0.772 & 0.820 & 6.605 \\
\hline 24/10/2001_28/04/2003 & 0.779 & 0.046 & 0.466 & 0.513 & 1.599 \\
\hline 29/04/2003_06/07/2004 & 1.756 & 0.187 & 0.476 & 0.663 & 5.214 \\
\hline 07/07/2004_02/02/2006 & 1.546 & 0.100 & 0.384 & 0.484 & 2.994 \\
\hline 03/02/2006_18/08/2009 & 0.745 & 0.135 & 0.729 & 0.864 & 5.466 \\
\hline 19/08/2009_15/08/2014 & 0.946 & 0.014 & 0.549 & 0.562 & 2.162 \\
\hline 16/08/2014_03/09/2015 & 0.217 & 0.011 & 0.930 & 0.941 & 3.664 \\
\hline 04/09/2015_28/12/2016 & 1.343 & 0.252 & 0.138 & 0.390 & 2.201 \\
\hline 29/12/2016_23/05/2017 & 0.210 & 0.197 & 0.547 & 0.744 & 0.818 \\
\hline 24/05/2017_29/03/2019 & 0.530 & 0.144 & 0.646 & 0.790 & 2.527 \\
\hline
\end{tabular}

Volatility Breaks in GLENMARK

\begin{tabular}{|c|c|c|c|c|c|}
\hline \multicolumn{6}{|c|}{ Volatility Breaks in GLENMARK } \\
\hline \multicolumn{6}{|c|}{ Date of commencement of Derivative trading: 28-09-2013 } \\
\hline 25/02/2000_11/12/2001 & 0.396 & 0.058 & 0.907 & 0.965 & 11.238 \\
\hline 12/12/2001_05/07/2002 & 0.479 & -0.120 & 1.060 & 0.940 & 8.007 \\
\hline 06/07/2002_30/12/2004 & 1.311 & 0.194 & 0.669 & 0.864 & 9.611 \\
\hline 31/12/2004_17/11/2006 & 0.717 & 0.165 & 0.764 & 0.928 & 9.994 \\
\hline 18/11/2006_29/09/2008 & 1.830 & 0.157 & 0.630 & 0.786 & 8.553 \\
\hline 30/09/2008_02/11/2009 & -0.021 & 0.109 & 0.898 & 1.007 & 3.062 \\
\hline 03/11/2009_10/02/2010 & 0.513 & 0.038 & 0.868 & 0.906 & 5.461 \\
\hline 11/02/2010_20/05/2011 & 0.732 & 0.155 & 0.718 & 0.872 & 5.719 \\
\hline 21/05/2011_16/02/2016 & 0.684 & 0.060 & 0.762 & 0.823 & 3.856 \\
\hline 17/02/2016_02/06/2017 & 0.954 & 0.366 & 0.397 & 0.763 & 4.021 \\
\hline 03/06/2017_29/03/2019 & 1.270 & 0.067 & 0.449 & 0.516 & 2.623 \\
\hline
\end{tabular}




\begin{tabular}{|c|c|c|c|c|c|}
\hline Period & $\omega$ & $\alpha$ & B & $\begin{array}{l}\text { Total Persistence: } \\
\qquad(\alpha+\beta)\end{array}$ & $\begin{array}{l}\text { Unconditional Volatility: } \\
\qquad \omega /(1-\alpha-\beta)\end{array}$ \\
\hline \multicolumn{6}{|c|}{ Volatility Breaks in GRASIM } \\
\hline \multicolumn{6}{|c|}{ Date of commencement of Derivative trading: 02-07-2001 } \\
\hline 05/01/2000_04/10/2001 & 5.439 & 0.159 & 0.458 & 0.617 & 14.200 \\
\hline 05/10/2001_17/06/2003 & 0.006 & -0.021 & 1.017 & 0.996 & 1.761 \\
\hline 18/06/2003_16/07/2004 & 0.793 & 0.060 & 0.815 & 0.875 & 6.353 \\
\hline 17/07/2004_12/09/2005 & 0.480 & 0.033 & 0.692 & 0.725 & 1.749 \\
\hline 13/09/2005_13/03/2007 & 0.331 & 0.224 & 0.736 & 0.960 & 8.348 \\
\hline 14/03/2007_21/01/2008 & 0.720 & 0.038 & 0.748 & 0.786 & 3.368 \\
\hline 22/01/2008_06/10/2009 & 1.128 & 0.096 & 0.776 & 0.872 & 8.822 \\
\hline 07/10/2009_03/07/2012 & 1.592 & 0.241 & 0.100 & 0.341 & 2.415 \\
\hline $04 / 07 / 2012 \_25 / 07 / 2013$ & 1.019 & 0.167 & 0.085 & 0.252 & 1.362 \\
\hline 26/07/2013_10/03/2015 & 0.166 & 0.087 & 0.861 & 0.947 & 3.148 \\
\hline 11/03/2015_05/08/2016 & 0.354 & 0.104 & 0.623 & 0.728 & 1.299 \\
\hline 06/08/2016_29/03/2019 & 0.513 & 0.022 & 0.807 & 0.829 & 3.004 \\
\hline \multicolumn{6}{|c|}{ Volatility Breaks in HDFCBANK } \\
\hline \multicolumn{6}{|c|}{ Date of commencement of Derivative trading: 29-08-2003 } \\
\hline 05/01/2000_05/01/2001 & 1.467 & 0.188 & 0.651 & 0.839 & 9.129 \\
\hline 06/01/2001_09/10/2003 & 0.336 & 0.187 & 0.744 & 0.931 & 4.841 \\
\hline 10/10/2003_11/05/2004 & 0.968 & -0.108 & 0.862 & 0.754 & 3.933 \\
\hline $12 / 05 / 2004$ 18/05/2006 & 0.416 & 0.081 & 0.799 & 0.881 & 3.488 \\
\hline 19/05/2006_27/06/2008 & 0.160 & 0.056 & 0.921 & 0.976 & 6.773 \\
\hline 28/06/2008_22/12/2011 & 0.050 & 0.055 & 0.934 & 0.990 & 4.850 \\
\hline 23/12/2011_06/08/2013 & 0.904 & 0.023 & 0.553 & 0.576 & 2.133 \\
\hline 07/08/2013_06/10/2015 & 0.178 & 0.054 & 0.890 & 0.944 & 3.172 \\
\hline 07/10/2015_29/03/2019 & 0.216 & 0.052 & 0.833 & 0.885 & 1.872 \\
\hline \multicolumn{6}{|c|}{ Volatility Breaks in HDFC } \\
\hline \multicolumn{6}{|c|}{ Date of commencement of Derivative trading: 02-07-2001 } \\
\hline 05/01/2000_05/02/2001 & 0.602 & 0.241 & 0.724 & 0.965 & 17.222 \\
\hline 06/02/2001_16/10/2001 & 1.111 & 0.386 & 0.474 & 0.860 & 7.939 \\
\hline $17 / 10 / 2001 \_22 / 05 / 2003$ & 0.501 & 0.306 & 0.484 & 0.791 & 2.393 \\
\hline 23/05/2003_14/05/2004 & 1.487 & 0.145 & 0.448 & 0.593 & 3.656 \\
\hline $15 / 05 / 2004 \_30 / 03 / 2006$ & 0.548 & 0.028 & 0.770 & 0.798 & 2.712 \\
\hline $31 / 03 / 2006 \_28 / 11 / 2008$ & 0.352 & 0.103 & 0.855 & 0.958 & 8.337 \\
\hline 29/11/2008_08/11/2010 & 0.036 & 0.045 & 0.941 & 0.985 & 2.477 \\
\hline 09/11/2010_04/01/2012 & 3.047 & -0.064 & 0.009 & -0.055 & 2.889 \\
\hline 05/01/2012_03/06/2014 & 0.032 & 0.039 & 0.948 & 0.986 & 2.355 \\
\hline 04/06/2014_07/10/2015 & 0.598 & 0.024 & 0.521 & 0.545 & 1.314 \\
\hline 08/10/2015_29/03/2019 & 0.407 & 0.057 & 0.461 & 0.517 & 0.843 \\
\hline \multicolumn{6}{|c|}{ Volatility Breaks in HEROMOTOCO } \\
\hline \multicolumn{6}{|c|}{ Date of commencement of Derivative trading: 31-01-2003 } \\
\hline 05/01/2000_15/03/2001 & 0.263 & 0.071 & 0.893 & 0.964 & 7.290 \\
\hline 16/03/2001_25/04/2003 & 0.427 & 0.266 & 0.707 & 0.973 & 15.935 \\
\hline 26/04/2003_27/04/2004 & 0.073 & 0.082 & 0.900 & 0.981 & 3.916 \\
\hline 28/04/2004_26/07/2005 & 0.149 & 0.047 & 0.919 & 0.966 & 4.339 \\
\hline $27 / 07 / 2005 \_15 / 05 / 2006$ & 0.767 & 0.074 & 0.639 & 0.713 & 2.671 \\
\hline 16/05/2006_08/10/2007 & 0.305 & 0.015 & 0.919 & 0.935 & 4.669 \\
\hline 09/10/2007_31/07/2009 & 0.569 & 0.079 & 0.875 & 0.954 & 12.340 \\
\hline 01/08/2009_01/08/2011 & 0.271 & 0.060 & 0.861 & 0.921 & 3.418 \\
\hline 02/08/2011_24/10/2017 & 0.215 & 0.071 & 0.874 & 0.946 & 3.953 \\
\hline 25/10/2017_08/06/2018 & 0.484 & -0.111 & 0.976 & 0.865 & 3.582 \\
\hline 09/06/2018_29/03/2019 & 0.179 & 0.081 & 0.869 & 0.950 & 3.598 \\
\hline
\end{tabular}




\begin{tabular}{|c|c|c|c|c|c|}
\hline Period & $\omega$ & $\alpha$ & B & $\begin{array}{l}\text { Total Persistence: } \\
\qquad(\alpha+b)\end{array}$ & $\begin{array}{l}\text { Unconditional Volatility: } \\
\qquad \omega /(1-\alpha-6)\end{array}$ \\
\hline \multicolumn{6}{|c|}{ Volatility Breaks in ICICIBANK } \\
\hline \multicolumn{6}{|c|}{ Date of commencement of Derivative trading: 31-01-2003 } \\
\hline 05/01/2000_11/04/2000 & 0.748 & -0.161 & 1.133 & 0.972 & 26.559 \\
\hline 12/04/2000_01/10/2001 & 8.059 & 0.329 & 0.179 & 0.508 & 16.380 \\
\hline 02/10/2001_05/07/2002 & 1.035 & 0.153 & 0.716 & 0.869 & 7.885 \\
\hline 06/07/2002_21/03/2003 & 0.198 & 0.054 & 0.897 & 0.950 & 3.989 \\
\hline 22/03/2003_11/05/2004 & 2.431 & 0.143 & 0.498 & 0.641 & 6.771 \\
\hline 12/05/2004_28/02/2005 & 0.043 & -0.054 & 1.041 & 0.987 & 3.219 \\
\hline 29/02/2005_12/10/2007 & 0.526 & 0.062 & 0.822 & 0.884 & 4.531 \\
\hline 13/10/2007_18/08/2009 & 0.778 & 0.109 & 0.857 & 0.966 & 22.936 \\
\hline 19/08/2009_16/07/2013 & 0.106 & 0.042 & 0.930 & 0.973 & 3.868 \\
\hline 17/07/2013_24/07/2015 & 0.034 & 0.003 & 0.985 & 0.988 & 2.970 \\
\hline 25/07/2015_16/11/2016 & 3.588 & 0.050 & 0.198 & 0.249 & 4.776 \\
\hline 17/11/2016_29/03/2019 & 2.071 & -0.008 & 0.357 & 0.349 & 3.181 \\
\hline \multicolumn{6}{|c|}{ Volatility Breaks in IDEA } \\
\hline \multicolumn{6}{|c|}{ Date of commencement of Derivative trading: 08-03-2007 } \\
\hline 13/03/2007_10/08/2007 & 1.942 & -0.050 & 0.589 & 0.540 & 4.219 \\
\hline 11/08/2007_15/05/2009 & 0.982 & 0.093 & 0.831 & 0.923 & 12.803 \\
\hline $16 / 05 / 2009 \_06 / 08 / 2010$ & 0.384 & 0.004 & 0.935 & 0.940 & 6.357 \\
\hline 07/08/2010_04/06/2013 & 3.145 & 0.198 & 0.007 & 0.205 & 3.958 \\
\hline 05/06/2013_12/01/2017 & 3.275 & 0.150 & 0.600 & 0.750 & 13.101 \\
\hline 13/01/2017_29/03/2019 & 7.650 & 0.306 & -0.082 & 0.224 & 9.861 \\
\hline \multicolumn{6}{|c|}{ Volatility Breaks in IBULHSGFIN } \\
\hline \multicolumn{6}{|c|}{ Date of commencement of Derivative trading: 30-09-2010 } \\
\hline 26/07/2013_19/09/2013 & 10.009 & 0.113 & -0.079 & 0.034 & 10.358 \\
\hline 20/09/2013_02/06/2014 & 1.584 & 0.032 & 0.771 & 0.803 & 8.039 \\
\hline 03/06/2014_22/03/2016 & 1.929 & 0.037 & 0.589 & 0.626 & 5.158 \\
\hline 23/03/2016_01/11/2018 & 0.271 & 0.086 & 0.855 & 0.942 & 4.641 \\
\hline 02/11/2018_29/03/2019 & 3.118 & -0.063 & 0.716 & 0.652 & 8.969 \\
\hline \multicolumn{6}{|c|}{ Volatility Breaks in INDUSINDBK } \\
\hline \multicolumn{6}{|c|}{ Date of commencement of Derivative trading: 29-10-2010 } \\
\hline $05 / 01 / 2000 \_15 / 03 / 2001$ & 2.278 & 0.189 & 0.655 & 0.844 & 14.638 \\
\hline 16/03/2001_06/02/2002 & 2.859 & 0.356 & 0.041 & 0.397 & 4.743 \\
\hline $07 / 02 / 2002 \_05 / 05 / 2003$ & 0.372 & 0.081 & 0.855 & 0.937 & 5.862 \\
\hline 06/05/2003_07/12/2006 & 1.365 & 0.118 & 0.754 & 0.872 & 10.630 \\
\hline 08/12/2006_09/03/2007 & 0.969 & -0.211 & 1.177 & 0.966 & 28.330 \\
\hline $10 / 03 / 2007 \_22 / 07 / 2009$ & 0.736 & 0.094 & 0.872 & 0.966 & 21.552 \\
\hline 23/07/2009_02/06/2010 & 3.850 & 0.260 & 0.223 & 0.483 & 7.450 \\
\hline 03/06/2010_02/04/2012 & 5.351 & 0.184 & -0.181 & 0.002 & 5.364 \\
\hline 03/04/2012_20/06/2014 & 0.049 & 0.057 & 0.933 & 0.989 & 4.644 \\
\hline 21/06/2014_16/11/2016 & 0.362 & 0.034 & 0.808 & 0.842 & 2.292 \\
\hline 16/11/2016_29/03/2019 & 0.127 & 0.101 & 0.833 & 0.935 & 1.957 \\
\hline \multicolumn{6}{|c|}{ Volatility Breaks in INFRATEL } \\
\hline \multicolumn{6}{|c|}{ Date of commencement of Derivative trading: 24-09-2015 } \\
\hline $28 / 12 / 2012 \_07 / 06 / 2013$ & 1.175 & 0.146 & 0.558 & 0.704 & 3.962 \\
\hline 08/06/2013_20/11/2014 & 0.056 & 0.039 & 0.940 & 0.979 & 2.657 \\
\hline 21/11/2014_24/09/2015 & 0.840 & 0.032 & 0.703 & 0.735 & 3.169 \\
\hline 25/09/2015_31/01/2017 & 1.287 & -0.019 & 0.264 & 0.245 & 1.705 \\
\hline 01/02/2017_29/03/2019 & 1.037 & 0.276 & 0.123 & 0.400 & 1.726 \\
\hline \multicolumn{6}{|c|}{ Volatility Breaks in INDIGO } \\
\hline \multicolumn{6}{|c|}{ Date of commencement of Derivative trading: 31-03-2017 } \\
\hline 12/11/2015_22/01/2016 & 11.610 & 0.304 & -0.109 & 0.196 & 14.436 \\
\hline 23/01/2016_16/02/2016 & 10.775 & -0.123 & 0.663 & 0.540 & 23.432 \\
\hline 17/02/2016_19/08/2016 & 2.533 & -0.050 & 0.600 & 0.550 & 5.632 \\
\hline
\end{tabular}




\begin{tabular}{|c|c|c|c|c|c|}
\hline Period & $\omega$ & $\alpha$ & B & $\begin{array}{l}\text { Total Persistence: } \\
\qquad(\alpha+\beta)\end{array}$ & $\begin{array}{l}\text { Unconditional Volatility: } \\
\qquad \omega /(1-\alpha-\beta)\end{array}$ \\
\hline 20/08/2016_27/04/2017 & 2.401 & 0.212 & -0.098 & 0.114 & 2.711 \\
\hline 28/04/2017_29/03/2019 & 0.977 & 0.024 & 0.828 & 0.852 & 6.613 \\
\hline \multicolumn{6}{|c|}{ Volatility Breaks in INFY } \\
\hline \multicolumn{6}{|c|}{ Date of commencement of Derivative trading: 02-07-2001 } \\
\hline 05/01/2000_27/02/2001 & 0.710 & 0.100 & 0.852 & 0.951 & 14.612 \\
\hline 28/02/2001_03/11/2001 & 6.251 & -0.196 & 1.046 & 0.850 & 41.605 \\
\hline 05/11/2001_17/05/2004 & 1.033 & 0.108 & 0.778 & 0.886 & 9.097 \\
\hline 18/05/2004_28/03/2006 & 0.447 & 0.005 & 0.810 & 0.814 & 2.408 \\
\hline $29 / 03 / 2006 \quad 24 / 07 / 2006$ & 5.691 & 0.336 & -0.126 & 0.210 & 7.206 \\
\hline 25/07/2006_01/05/2009 & 0.053 & 0.061 & 0.931 & 0.992 & 6.624 \\
\hline $02 / 05 / 2009 \_12 / 07 / 2012$ & 0.628 & 0.230 & 0.598 & 0.828 & 3.650 \\
\hline 13/07/2012_11/01/2013 & 0.360 & 0.030 & 0.737 & 0.767 & 1.545 \\
\hline $12 / 01 / 2013 \_13 / 03 / 2014$ & 0.560 & 1.277 & 0.205 & 1.482 & -1.163 \\
\hline 14/03/2014_18/07/2016 & 0.850 & -0.018 & 0.699 & 0.681 & 2.661 \\
\hline 19/07/2016_3/29/2019 & 1.292 & 0.170 & 0.137 & 0.307 & 1.864 \\
\hline \multicolumn{6}{|c|}{ Volatility Breaks in ITC } \\
\hline \multicolumn{6}{|c|}{ Date of commencement of Derivative trading: 02-07-2001 } \\
\hline 05/01/2000_07/02/2001 & -0.038 & -0.023 & 1.026 & 1.003 & 11.359 \\
\hline 08/02/2001_09/11/2001 & 3.004 & 0.577 & 0.097 & 0.674 & 9.213 \\
\hline $10 / 11 / 2001$ & 0.579 & 0.078 & 0.662 & 0.740 & 2.226 \\
\hline $22 / 05 / 2002 \_01 / 02 / 2005$ & 0.387 & 0.111 & 0.759 & 0.869 & 2.959 \\
\hline $02 / 02 / 2005$ & 0.744 & 0.001 & 0.565 & 0.566 & 1.715 \\
\hline $06 / 09 / 2005 \_12 / 11 / 2007$ & 0.357 & 0.076 & 0.836 & 0.912 & 4.045 \\
\hline $13 / 11 / 2007 \quad 25 / 08 / 2009$ & 0.459 & 0.084 & 0.845 & 0.928 & 6.416 \\
\hline 26/08/2009_10/11/2014 & 0.561 & 0.096 & 0.629 & 0.725 & 2.039 \\
\hline $11 / 11 / 2014 \_20 / 07 / 2017$ & 2.498 & 0.272 & -0.110 & 0.162 & 2.980 \\
\hline 21/07/2017_29/03/2019 & 0.202 & 0.015 & 0.842 & 0.857 & 1.409 \\
\hline
\end{tabular}

Volatility Breaks in JUSTDIAL

\begin{tabular}{|c|c|c|c|c|c|}
\hline \multicolumn{6}{|c|}{ Date of commencement of Derivative trading: 02-04-2013 } \\
\hline $12 / 07 / 2012 \_06 / 06 / 2013$ & 0.360 & 0.030 & 0.737 & 0.767 & 1.545 \\
\hline 07/06/2013_04/10/2013 & 0.296 & -0.186 & 1.113 & 0.927 & 4.057 \\
\hline 05/10/2013_29/05/2014 & 1.163 & 0.056 & 0.877 & 0.933 & 17.414 \\
\hline $30 / 05 / 2014 \_28 / 01 / 2016$ & 5.033 & 0.366 & -0.084 & 0.282 & 7.013 \\
\hline 29/01/2016_09/03/2016 & 3.886 & -0.478 & 1.427 & 0.950 & 77.137 \\
\hline 10/10/2017_29/05/2018 & 2.735 & 0.242 & 0.632 & 0.873 & 21.582 \\
\hline 30/05/2018_29/03/2019 & 2.368 & 0.094 & 0.608 & 0.702 & 7.942 \\
\hline \multicolumn{6}{|c|}{ Volatility Breaks in KOTAKBANK } \\
\hline \multicolumn{6}{|c|}{ Date of commencement of Derivative trading: 29-12-2005 } \\
\hline 05/01/2000_16/11/2001 & 3.256 & 0.310 & 0.540 & 0.850 & 21.713 \\
\hline $17 / 11 / 2001[01 / 01 / 2003$ & 0.142 & 0.266 & 0.784 & 1.051 & -2.803 \\
\hline 02/01/2003_18/11/2004 & 0.172 & 0.096 & 0.888 & 0.984 & 10.853 \\
\hline 19/11/2004_04/05/2006 & 3.323 & 0.085 & 0.411 & 0.497 & 6.601 \\
\hline 05/05/2006_18/01/2008 & 2.728 & 0.259 & 0.453 & 0.712 & 9.478 \\
\hline $19 / 01 / 2008 \_18 / 08 / 2009$ & 2.281 & 0.079 & 0.815 & 0.894 & 21.560 \\
\hline 19/08/2009_07/06/2012 & 1.175 & 0.146 & 0.558 & 0.704 & 3.962 \\
\hline $08 / 06 / 2012 \_20 / 11 / 2014$ & 0.056 & 0.039 & 0.940 & 0.979 & 2.657 \\
\hline 21/11/2014_24/09/2015 & 0.840 & 0.032 & 0.703 & 0.735 & 3.169 \\
\hline 25/09/2015_31/01/2017 & 1.287 & -0.019 & 0.264 & 0.245 & 1.705 \\
\hline 01/02/2017_29/03/2019 & 1.037 & 0.276 & 0.123 & 0.400 & 1.726 \\
\hline \multicolumn{6}{|c|}{ Volatility Breaks in LT } \\
\hline \multicolumn{6}{|c|}{ Date of commencement of Derivative trading: 02-07-2001 } \\
\hline $05 / 01 / 2000 \_21 / 11 / 2001$ & -0.038 & -0.023 & 1.026 & 1.003 & 11.359 \\
\hline $22 / 11 / 2001 \_22 / 04 / 2004$ & 0.041 & 0.031 & 0.956 & 0.987 & 3.098 \\
\hline 23/04/2004_24/07/2006 & 1.172 & 0.283 & 0.532 & 0.815 & 6.352 \\
\hline
\end{tabular}




\begin{tabular}{|c|c|c|c|c|c|}
\hline Period & $\omega$ & $\alpha$ & B & $\begin{array}{l}\text { Total Persistence: } \\
\qquad(\alpha+\beta)\end{array}$ & $\begin{array}{l}\text { Unconditional Volatility: } \\
\qquad \omega /(1-\alpha-\beta)\end{array}$ \\
\hline 25/07/2006_02/02/2007 & 1.070 & -0.072 & 0.602 & 0.531 & 2.278 \\
\hline 03/02/2007_10/03/2008 & 0.540 & 0.205 & 0.742 & 0.947 & 10.227 \\
\hline 11/03/2008_08/09/2009 & 6.429 & 0.237 & 0.380 & 0.617 & 16.790 \\
\hline 09/09/2009_28/01/2011 & 2.361 & 0.120 & -0.251 & -0.131 & 2.087 \\
\hline $29 / 01 / 2011 \_11 / 12 / 2013$ & 0.071 & 0.049 & 0.935 & 0.985 & 4.583 \\
\hline 12/12/2013_13/01/2016 & 1.073 & -0.009 & 0.621 & 0.612 & 2.765 \\
\hline 14/01/2016_05/07/2016 & 2.895 & 0.753 & -0.085 & 0.668 & 8.710 \\
\hline 06/07/2016_13/09/2019 & 1.767 & 0.047 & -0.054 & -0.007 & 1.755 \\
\hline
\end{tabular}

Volatility Breaks in MARUTI

\begin{tabular}{|c|c|c|c|c|c|}
\hline \multicolumn{6}{|c|}{ Date of commencement of Derivative trading: 08-07-2003 } \\
\hline 15/03/2001_06/02/2002 & 2.859 & 0.356 & 0.041 & 0.397 & 4.743 \\
\hline 07/02/2002_05/12/2003 & 0.372 & 0.081 & 0.855 & 0.937 & 5.862 \\
\hline 06/12/2003_21/01/2005 & 0.187 & 0.098 & 0.866 & 0.964 & 5.223 \\
\hline 22/01/2005_05/08/2009 & 0.526 & 0.083 & 0.853 & 0.937 & 8.304 \\
\hline 05/08/2009_31/05/2010 & 0.048 & -0.065 & 1.045 & 0.980 & 2.422 \\
\hline 01/06/2010_19/08/2011 & 0.118 & -0.024 & 0.986 & 0.962 & 3.140 \\
\hline 20/08/2011_21/06/2013 & 2.590 & 0.232 & 0.087 & 0.319 & 3.804 \\
\hline 22/06/2013_17/12/2014 & 2.754 & 0.147 & -0.080 & 0.067 & 2.951 \\
\hline 18/12/2014_06/12/2016 & 0.547 & 0.195 & 0.602 & 0.798 & 2.703 \\
\hline 07/12/2016_29/03/2019 & 0.025 & 0.031 & 0.955 & 0.986 & 1.830 \\
\hline
\end{tabular}

Volatility Breaks in RELIANCE

\begin{tabular}{|c|c|c|c|c|c|}
\hline \multicolumn{6}{|c|}{ Volatility Breaks in RELIANCE } \\
\hline \multicolumn{6}{|c|}{ Date of commencement of Derivative trading: 29-11-2001 } \\
\hline 05/01/2000_28/02/2001 & 0.322 & 0.128 & 0.808 & 0.936 & 4.993 \\
\hline 28/02/2001_21/12/2001 & 1.941 & 0.386 & 0.471 & 0.857 & 13.560 \\
\hline 22/12/2001_02/08/2004 & 1.299 & 0.288 & 0.399 & 0.687 & 4.154 \\
\hline 03/08/2004_24/07/2006 & 1.832 & 0.870 & 0.072 & 0.942 & 31.407 \\
\hline 25/07/2006_24/12/2009 & 0.101 & 0.096 & 0.898 & 0.994 & 17.804 \\
\hline 25/12/2009_22/08/2011 & 1.164 & -0.014 & 0.510 & 0.496 & 2.309 \\
\hline 23/08/2011_02/04/2012 & 1.980 & -0.100 & 0.733 & 0.633 & 5.401 \\
\hline 03/04/2012_29/03/2019 & 0.372 & 0.067 & 0.774 & 0.840 & 2.332 \\
\hline \multicolumn{6}{|c|}{ Volatility Breaks in SBIN } \\
\hline \multicolumn{6}{|c|}{ Date of commencement of Derivative trading: 02-07-2001 } \\
\hline 05/01/2000_15/03/2001 & 0.263 & 0.071 & 0.893 & 0.964 & 7.290 \\
\hline $16 / 03 / 2001 \_25 / 09 / 2001$ & 0.427 & 0.266 & 0.707 & 0.973 & 15.935 \\
\hline 26/09/2001_27/04/2004 & 0.073 & 0.082 & 0.900 & 0.981 & 3.916 \\
\hline 28/04/2004_26/07/2005 & 0.149 & 0.047 & 0.919 & 0.966 & 4.339 \\
\hline 27/07/2005_15/05/2006 & 0.767 & 0.074 & 0.639 & 0.713 & 2.671 \\
\hline 16/05/2006_08/10/2007 & 0.305 & 0.015 & 0.919 & 0.935 & 4.669 \\
\hline 09/10/2007_31/07/2009 & 0.569 & 0.079 & 0.875 & 0.954 & 12.340 \\
\hline 01/08/2009_01/08/2011 & 0.271 & 0.060 & 0.861 & 0.921 & 3.418 \\
\hline 02/08/2011_24/10/2017 & 0.215 & 0.071 & 0.874 & 0.946 & 3.953 \\
\hline 25/10/2017_08/06/2018 & 0.484 & -0.111 & 0.976 & 0.865 & 3.582 \\
\hline 09/06/2018_29/03/2019 & 0.179 & 0.081 & 0.869 & 0.950 & 3.598 \\
\hline \multicolumn{6}{|c|}{ Volatility Breaks in TCS } \\
\hline \multicolumn{6}{|c|}{ Date of commencement of Derivative trading: 23-08-2004 } \\
\hline $27 / 04 / 2004 \_26 / 08 / 2004$ & 0.149 & 0.047 & 0.919 & 0.966 & 4.339 \\
\hline 27/08/2004_15/04/2005 & 0.634 & 0.012 & 0.608 & 0.619 & 1.666 \\
\hline $16 / 04 / 2005 \_25 / 07 / 2006$ & 0.463 & 0.169 & 0.709 & 0.878 & 3.796 \\
\hline 26/07/2006_06/07/2007 & 1.290 & 0.342 & 0.159 & 0.501 & 2.588 \\
\hline $07 / 07 / 200729 / 10 / 2008$ & 0.333 & 0.116 & 0.856 & 0.971 & 11.669 \\
\hline $30 / 10 / 2008-13 / 08 / 2009$ & 11.142 & 0.241 & -0.171 & 0.070 & 11.982 \\
\hline 14/08/2009_05/08/2011 & 1.133 & 0.134 & 0.460 & 0.594 & 2.794 \\
\hline 06/08/2011_10/05/2012 & 0.168 & 0.041 & 0.921 & 0.961 & 4.366 \\
\hline $11 / 05 / 2012 \_26 / 06 / 2013$ & 0.021 & -0.041 & 1.030 & 0.988 & 1.823 \\
\hline 27/06/2013_20/10/2014 & 0.808 & 0.027 & 0.692 & 0.719 & 2.873 \\
\hline
\end{tabular}




\begin{tabular}{|c|c|c|c|c|c|}
\hline Period & $\omega$ & $\alpha$ & B & $\begin{array}{l}\text { Total Persistence: } \\
\qquad(\alpha+\beta)\end{array}$ & $\begin{array}{l}\text { Unconditional Volatility: } \\
\qquad \omega /(1-\alpha-\beta)\end{array}$ \\
\hline 21/10/2014_29/12/2017 & 1.048 & 0.151 & 0.232 & 0.383 & 1.699 \\
\hline 30/12/2017_29/03/2019 & 0.363 & 0.047 & 0.799 & 0.846 & 2.353 \\
\hline \multicolumn{6}{|c|}{ Volatility Breaks in TATAELXSI } \\
\hline \multicolumn{6}{|c|}{ Date of commencement of Derivative trading: 26-02-2016 } \\
\hline 05/01/2000_01/10/2001 & 0.369 & 0.029 & 0.953 & 0.982 & 20.001 \\
\hline 02/10/2001_25/12/2003 & 3.042 & -0.007 & 0.590 & 0.584 & 7.307 \\
\hline $26 / 12 / 2003 \_29 / 03 / 2006$ & 1.135 & 0.211 & 0.675 & 0.886 & 9.962 \\
\hline 30/03/2006_29/11/2007 & 0.331 & 0.080 & 0.880 & 0.959 & 8.164 \\
\hline $30 / 11 / 2007+11 / 12 / 2008$ & 5.212 & 0.284 & 0.498 & 0.782 & 23.918 \\
\hline 12/12/2008_30/08/2011 & 0.938 & 0.222 & 0.644 & 0.865 & 6.976 \\
\hline $31 / 08 / 2011 \_23 / 05 / 2013$ & 1.213 & 0.019 & 0.608 & 0.627 & 3.251 \\
\hline 24/05/2013_16/07/2014 & 10.945 & 0.049 & -0.712 & -0.663 & 6.581 \\
\hline $17 / 07 / 2014+01 / 11 / 2017$ & 0.357 & 0.027 & 0.882 & 0.910 & 3.944 \\
\hline 02/11/2017_29/03/2019 & 0.959 & 0.072 & 0.568 & 0.641 & 2.670 \\
\hline \multicolumn{6}{|c|}{ Volatility Breaks in TATASTEEL } \\
\hline \multicolumn{6}{|c|}{ Date of commencement of Derivative trading: 02-07-2001 } \\
\hline 05/01/2000_27/07/2000 & 3.121 & 0.193 & 0.559 & 0.752 & 12.592 \\
\hline 28/07/2000_20/07/2001 & 1.703 & 0.276 & 0.534 & 0.810 & 8.986 \\
\hline $21 / 07 / 2001$ & 1.010 & 0.084 & 0.750 & 0.834 & 6.066 \\
\hline $13 / 08 / 2002 \_10 / 07 / 2003$ & 1.885 & 0.270 & -0.044 & 0.226 & 2.436 \\
\hline $11 / 07 / 2003 \_28 / 06 / 2006$ & 0.155 & 0.092 & 0.888 & 0.979 & 7.480 \\
\hline 29/06/2006_26/01/2007 & 0.250 & -0.002 & 0.923 & 0.921 & 3.177 \\
\hline 27/01/2007_23/05/2013 & 0.089 & 0.079 & 0.912 & 0.990 & 8.987 \\
\hline $24 / 05 / 2013 \_11 / 08 / 2015$ & 0.262 & 0.061 & 0.887 & 0.948 & 4.996 \\
\hline $12 / 08 / 2015 \_28 / 11 / 2016$ & 0.233 & 0.007 & 0.955 & 0.962 & 6.183 \\
\hline 29/11/2016_29/03/2019 & 5.508 & -0.035 & -0.640 & -0.674 & 3.289 \\
\hline \multicolumn{6}{|c|}{ Volatility Breaks in VEDL } \\
\hline \multicolumn{6}{|c|}{ Date of commencement of Derivative trading: 29-12-2006 } \\
\hline $05 / 01 / 2000 \_24 / 12 / 2001$ & 4.740 & 0.234 & 0.385 & 0.618 & 12.419 \\
\hline $25 / 12 / 2001+07 / 04 / 2003$ & 0.624 & 0.096 & 0.839 & 0.935 & 9.618 \\
\hline 08/04/2003_08/03/2007 & 2.851 & 0.203 & 0.597 & 0.800 & 14.255 \\
\hline 09/03/2007_26/03/2008 & 0.698 & 0.468 & 0.591 & 1.059 & -11.844 \\
\hline 27/03/2008_08/08/2016 & 0.206 & 0.076 & 0.904 & 0.980 & 10.189 \\
\hline 09/08/2016_29/05/2017 & 5.367 & -0.044 & 0.112 & 0.068 & 5.756 \\
\hline 30/05/2017_29/03/2019 & 2.337 & -0.018 & 0.582 & 0.565 & 5.369 \\
\hline \multicolumn{6}{|c|}{ Volatility Breaks in YESBANK } \\
\hline \multicolumn{6}{|c|}{ Date of commencement of Derivative trading: 06-09-2007 } \\
\hline 14/07/2005_03/02/2008 & 2.310 & 0.158 & 0.510 & 0.668 & 6.951 \\
\hline $04 / 02 / 2008 \quad 16 / 03 / 2012$ & 0.244 & 0.112 & 0.870 & 0.982 & 13.216 \\
\hline $17 / 03 / 2012 \_03 / 03 / 2016$ & 0.196 & 0.068 & 0.900 & 0.968 & 6.100 \\
\hline 04/03/2016_24/08/2018 & 0.676 & 0.083 & 0.689 & 0.772 & 2.969 \\
\hline 25/08/2018_29/03/2019 & 9.789 & -0.024 & 0.577 & 0.553 & 21.892 \\
\hline \multicolumn{6}{|c|}{ Volatility Breaks in ZEEL } \\
\hline \multicolumn{6}{|c|}{ Date of commencement of Derivative trading: 07-10-2010 } \\
\hline 05/01/2000_12/10/2001 & 3.815 & 0.137 & 0.740 & 0.877 & 31.114 \\
\hline $13 / 10 / 2001 \_08 / 01 / 2004$ & 2.143 & 0.105 & 0.698 & 0.803 & 10.882 \\
\hline $09 / 01 / 2004 \_02 / 10 / 2008$ & 4.177 & 0.163 & 0.307 & 0.470 & 7.887 \\
\hline $03 / 10 / 2008 \_28 / 10 / 2009$ & 0.719 & 0.114 & 0.851 & 0.966 & 20.982 \\
\hline 29/10/2009_09/06/2010 & 3.145 & 0.321 & 0.032 & 0.354 & 4.865 \\
\hline $10 / 06 / 2010 \_29 / 11 / 2015$ & 0.538 & 0.053 & 0.802 & 0.855 & 3.710 \\
\hline $30 / 11 / 2015+05 / 10 / 2018$ & 0.562 & 0.050 & 0.649 & 0.699 & 1.868 \\
\hline 06/10/2018_29/03/2019 & 17.897 & 0.138 & -0.556 & -0.417 & 12.629 \\
\hline
\end{tabular}

